2012

\title{
Is U.S. Multinational Dividend Repatriation Policy Influenced by Reporting Incentives?
}

\author{
Jennifer L. Blouin \\ University of Pennsylvania \\ Linda K. Krull \\ University of Oregon \\ Leslie A. Robinson \\ Dartmouth College
}

\begin{abstract}
This study finds evidence that public-company reporting by U.S. multinational corporations (MNCs) creates disincentives to repatriate foreign earnings to the U.S. and contributes to the accumulation of cash abroad. MNCs operate under U.S. international tax laws and financial reporting rules and face two potential consequences when they repatriate foreign earnings: a cash payment for repatriation taxes and a reduction in reported accounting earnings. Using a confidential dataset of financial and operating characteristics of foreign affiliates of MNCs combined with public-company data, we examine how repatriation amounts vary across firms that face relatively strong reporting incentives to defer an accounting expense. Our results suggest that reporting incentives reduce repatriations by about 17 to 21 percent annually.
\end{abstract}

Keywords: repatriation policy; reporting incentives; international tax policy.

Data Availability: Bureau of Economic Analysis (BEA) data were made available to the authors under a legal confidentiality arrangement; all non-BEA data are available from public sources.

The authors thank Rosanne Altshuler, Fritz Foley, Matthew Slaughter, Ray Mataloni, and Bill Zeile for helpful suggestions regarding BEA data. The authors also thank Tom Omer and Harry Evans (editors), two anonymous reviewers, John Graham, David Guenther, Michelle Hanlon, Tim McDonald, Lillian Mills, Richard Sansing, Joel Slemrod, Doug Shackelford, Terry Shevlin, and participants at the 2009 UNC/KPMG Tax Research Symposium, 2009 UBCOW Conference, and 2009 JATA conference, and workshop participants at Northwestern University, University of California, Davis, Stanford University, Temple University, The University of Texas, Yale University, The University of Arizona, Arizona State University, Columbia University, and the University of Pennsylvania Wharton School for helpful comments. Professor Blouin appreciates the financial support from the Terker Research Fellowship awarded by the Rodney L. White Center for Financial Research.

The statistical analysis of firm-level data on U.S. multinational companies was conducted at the Bureau of Economic Analysis, Department of Commerce under arrangements that maintain legal confidentiality requirements. The views expressed are those of the authors and do not reflect official positions of the U.S. Department of Commerce.

Editor's note: Accepted by John Harry Evans III, with thanks to Thomas Omer for serving as editor on a previous version.

Submitted: February 2011 Accepted: April 2012 Published Online: April 2012 


\section{INTRODUCTION}

$\mathrm{T}$ he U.S. tax system plays a role in the ability of U.S. multinational corporations (MNCs) to compete in the global marketplace. Various critics of U.S. international tax policy argue that the system of worldwide taxation has a negative effect on the competitiveness of U.S. firms and creates incentives to leave or "park" foreign profits overseas. Consistent with this incentive, MNCs held an estimated $\$ 403$ billion of undistributed earnings in foreign countries at the end of 1999 (Brumbaugh 2003), which doubled to $\$ 804$ billion by the end of 2004 (Redmiles 2008). As a result, policy makers and regulators have an interest in understanding factors that foster the accumulation of earnings in foreign countries.

Existing literature identifies several factors that contribute to this accumulation. Growing evidence that repatriations decrease when the tax cost of repatriating increases (e.g., Hines and Hubbard 1990; Altshuler and Newlon 1993; Altshuler et al. 1995; Grubert 1998; Desai et al. 2001; Desai et al. 2007) suggests that taxes are an important factor. Other evidence suggests that firms with high foreign profitability increase both foreign retained earnings and dividend repatriations (Grubert 1998), and that firms with domestic financing needs, domestic investment needs, and intra-firm agency problems repatriate more foreign earnings (Desai et al. 2007).

More recently, accounting research investigates how accounting for income taxes contributes to the accumulation of foreign earnings abroad. Shackelford et al. (2011) model the effect of financial reporting on firms' real decisions and note that repatriation is an area for which such forces have potential importance. Graham et al. (2011) find that, when asked which factors are important in the decision to reinvest foreign earnings outside of the U.S., executives rate the importance of deferring an accounting expense for repatriation taxes as high as deferring a cash payment for repatriation taxes. We explore this issue in more detail by studying the extent to which reporting incentives to defer an accounting expense affect managers' actual repatriation decisions. ${ }^{1}$

As discussed in the "Repatriation and Tax Law" section, tax laws prescribe the amount and timing of cash payments for U.S. taxes on repatriations of foreign earnings, whereas accounting rules, described in the "Repatriation and Financial Reporting Rules" section, prescribe the amount and timing of the income tax expense recorded in the financial statements. Tax laws require MNCs to pay repatriation taxes when a foreign affiliate remits its earnings as a dividend to the U.S. parent. $^{2}$ Financial reporting rules require MNCs to recognize a repatriation tax expense for actual or expected repatriation taxes when earnings are generated in foreign affiliates, regardless of whether they are repatriated. However, an exception to this general rule (hereafter, the Indefinite Reversal Exception) allows them to defer recognition of a repatriation tax expense until repatriation if the earnings are indefinitely reinvested abroad (hereafter, permanently reinvested earnings or PRE).

The Indefinite Reversal Exception introduces financial reporting consequences to repatriation for MNCs that routinely utilize the PRE designation. Specifically, when an MNC reinvests foreign earnings and designates them as PRE, it recognizes foreign pre-tax earnings with no corresponding repatriation tax expense. If the MNC eventually repatriates the earnings, then it must recognize a

\footnotetext{
${ }^{1}$ We obtain the data for this study from the Bureau of Economic Analysis (BEA) Survey of U.S. Direct Investment Abroad. Participation in the BEA surveys is mandated by federal law pursuant to the International Investment and Trade in Services Survey Act (P.L. 94-472, 90 Stat. 2059, 22 U.S.C. 3101-3108) and willful failure to participate can result in monetary fines and/or imprisonment. Furthermore, the BEA staff reviews the survey responses. However, as with any data source, errors occur and compliance may be less than 100 percent. See Mataloni (2003) and http://www.bea.gov/surveys/diasurv.htm for detailed information on BEA data.

2 The BEA defines a foreign affiliate as a foreign business enterprise in which there is direct or indirect equity investment of more than 10 percent by a U.S. entity. An affiliate can be any organization, association, branch, estate, trust, venture, or subsidiary that exists to make a profit. However, we use the term foreign affiliate to refer only to foreign subsidiaries over which the U.S. parent has control, i.e., greater than a 50 percent equity investment.
} 
repatriation tax expense with no corresponding pre-tax earnings, potentially decreasing after-tax earnings. As a result, the Indefinite Reversal Exception creates reporting incentives to defer repatriation incremental to the cash tax incentive documented in existing literature.

These reporting incentives vary across firms in at least two ways. First, existing research finds that some firms have a stronger focus on reported earnings than do other firms. For example, evidence suggests that public firms are more likely than private firms to use accounting methods and tax-planning methods that increase earnings (Penno and Simon 1986; Cloyd et al. 1996; Badertscher et al. 2011) and, among public firms, those with greater ownership by dedicated investors exhibit a lesser tendency to fixate on earnings (Bushee 1998). Second, the magnitude of the earnings effect of repatriation will vary depending on a firm's use of the Indefinite Reversal Exception. All else equal, firms that have designated more undistributed foreign earnings as PRE have a larger unrecognized tax expense and a greater potential to experience a decrease in earnings upon repatriation.

We use this variation to develop two categories of proxies that capture the magnitude of reporting incentives to defer repatriation. The first category, our capital markets measures, captures the magnitude of any anticipated negative capital market response to the repatriation tax expense. Within this category, we estimate two measures of reporting incentives. Our first measure captures public versus private firm ownership because the financial reporting literature suggests that private firms are relatively less sensitive to capital market pressures (e.g., Cloyd et al. 1996; Penno and Simon 1986; Wolfson 1993; Graham et al. 2011). Therefore, on average, public firms face greater reporting incentives to avoid repatriation than private firms. Our second measure combines several proxies that capture the extent to which public firm managers believe that their firms' earnings face relatively more intense capital market scrutiny-earnings response coefficients, the firm's history of meeting analyst expectations, and ownership by dedicated investors. On average, we expect managers to have stronger reporting incentives to avoid repatriation as earnings response coefficients increase (because the stock price decrease will be larger per dollar of repatriation tax expense), as the history of meeting analyst forecasts improves (because the firm's history of meeting analyst forecasts suggests a greater concern about earnings) and as the proportion of shares held by dedicated institutional investors decreases (because these investors are more sophisticated financial statement users with a long-term focus).

The second category of proxies for reporting incentives, our earnings measure, uses PRE to identify firms with a relatively large unrecognized tax expense and therefore a greater potential to experience an earnings decrease when repatriating. Upon repatriation, firms that routinely designate foreign earnings as PRE must recognize a tax expense that they regularly deferred under the Indefinite Reversal Exception. Thus, we expect that reporting incentives to avoid repatriation are, on average, greater for firms that make extensive use of the PRE designation.

The effects of tax laws and financial reporting rules on repatriations are interrelated because the cash payment for repatriation taxes and the financial statement expense for repatriation taxes both depend on the repatriation tax rate. Due to this interdependence, we test whether firms are more sensitive to the repatriation tax rate as reporting incentives to defer repatriation increase in magnitude.

We test our predictions using a sample of 479 public and 98 private MNCs from 1999 through 2004. After controlling for investment opportunities, size, financing constraints, tax planning, and country-level attributes, we find that repatriation by public firms is more sensitive to the repatriation tax rate than repatriation by private firms. We also find that repatriation by public firms for which the recognition of a repatriation tax expense is expected to affect firm value more negatively is more sensitive to the repatriation tax rate than repatriation by other public firms. Finally, repatriation by public firms that make extensive use of the PRE designation under the Indefinite Reversal Exception is more sensitive to the repatriation tax rate than repatriation by other public firms. Our 
estimates suggest that firms with high reporting incentives repatriate, on average, 16.6 to 21.4 percent less per year than firms with low reporting incentives. This estimate amounts to a total of $\$ 6.7$ billion annually for our sample of public firms and $\$ 1.5$ billion annually for public firms with high amounts of PRE.

We evaluate the robustness of our results and the adequacy of our proxies for reporting incentives using two additional analyses. First, we conduct subsample analyses and find that the sensitivity of repatriation to the repatriation tax rate is greater when firms are more likely to recognize repatriation tax expense upon repatriation and anticipate a negative capital market response to this expense. Second, we extend Foley et al. (2007) to show that the effect of repatriation taxes on the accumulation of foreign cash in public companies is exacerbated by reporting incentives. Collectively, our empirical results consistently demonstrate that reporting incentives deter repatriation of foreign earnings.

This study makes important contributions to the literature by informing the broader policy debate about necessary reforms to our international tax system and by aiding our understanding of how accounting for income taxes affects repatriation behavior. The accounting literature has only very recently begun to explore the effect of accounting standards on repatriation decisions. Graham et al. (2011) provides useful initial insight by surveying executives. While their evidence tells us what managers believe is important with respect to repatriation taxes, we study whether financial accounting consequences have an economically meaningful effect on managers' actions. Specifically, we identify and measure the mechanisms that create reporting incentives to defer recognition of the repatriation tax expense and estimate the magnitude of their effect on repatriation amounts. Thus, our results shed light on the extent to which accounting standards contribute to the growing pool of undistributed foreign earnings that U.S. firms hold in foreign countries.

Section II provides a background and develops our hypotheses. Sections III and IV describe our data and our research design, respectively. Section V discusses our main results and Section VI provides results from supplemental analyses. Section VII concludes.

\section{BACKGROUND AND HYPOTHESES}

We analyze how tax laws and financial reporting rules interact to influence repatriation decisions. Therefore, to motivate our hypotheses, we first describe the tax and financial reporting rules that govern the repatriation of foreign earnings.

\section{Repatriation and Tax Law}

When a foreign affiliate pays a dividend to its U.S. parent, the amount of repatriation taxes equals the dividend grossed-up for foreign taxes paid times the U.S. statutory tax rate minus the foreign tax credit. Generally, the foreign tax credit equals the amount of foreign taxes paid on the foreign earnings up to the amount of the U.S. tax liability. If the foreign tax rate is greater than the U.S. tax rate, then the MNC owes no incremental U.S. taxes on repatriated earnings. Further, if an MNC repatriates earnings from more than one country, then it can use tax credits generated in hightax countries to offset U.S. taxes on repatriations from low-tax countries. Therefore, the incremental tax rate on repatriation can be thought of as the difference between the U.S. tax rate and the average foreign tax rate paid on repatriated foreign earnings.

From a tax perspective, an MNC with foreign earnings has two choices. It can reinvest the earnings abroad or repatriate the earnings. When the MNC reinvests the earnings abroad, the current taxes paid on foreign earnings consists only of foreign income taxes. Alternatively, when the $\mathrm{MNC}$ repatriates the earnings, the current taxes paid on foreign earnings consists of both foreign income taxes and U.S. repatriation taxes. Thus, tax laws-not financial reporting rules-determine when firms pay repatriation taxes. 
Existing work on repatriation decisions finds that repatriations are negatively related to the repatriation tax rate. Hartman (1985) shows theoretically that, when after-tax returns and tax rates are constant over time, the repatriation tax rate does not affect the repatriation decision because all foreign earnings will eventually be taxed at the U.S. tax rate. However, subsequent empirical evidence suggests that repatriations are decreasing in the repatriation tax rate (e.g., Hines and Hubbard 1990; Altshuler and Newlon 1993; Grubert 1998; Desai et al. 2001, 2007). Altshuler et al. (1995) reconcile theoretical work with empirical evidence by recognizing that tax rates are not constant over time. The authors estimate transitory and permanent components of firms' repatriation tax rates and find that dividend repatriations are negatively related to the transitory component and are not related to the permanent component. In contrast to evidence that U.S. tax law generally deters repatriation, Altshuler and Grubert (2003) describe sophisticated tax-planning strategies that allow low-tax affiliates to avoid repatriation taxes, but note that this type of tax planning is costly.

\section{Repatriation and Financial Reporting Rules}

From a financial reporting perspective, an MNC that reinvests foreign earnings abroad has two choices. The MNC can either currently recognize an expense for expected repatriation taxes on current earnings or it can use the Indefinite Reversal Exception to defer recognition of a repatriation tax expense until it repatriates the earnings. ${ }^{3}$ Thus, financial reporting rules-not tax lawsdetermine when firms recognize the financial statement expense for repatriation taxes.

Once a firm designates foreign earnings as PRE, repatriation of these earnings in a subsequent accounting period will, all else equal, decrease earnings relative to prior periods because it must recognize the repatriation tax expense that it deferred in prior years. As a result, accounting expense recognition is an additional consequence of repatriation when firms repatriate earnings that were previously designated as PRE.

Some MNCs use the PRE designation extensively. To illustrate, Bear Sterns and Company (2005) find that the S\&P 500 report $\$ 420$ billion of PRE at the end of 2002, and Zion et al. (2010) find that these firms report nearly $\$ 1$ trillion of PRE at the end of 2008. In addition, existing research finds evidence that deferral of the financial statement expense for repatriation taxes is an important factor in the decision to designate undistributed foreign earnings as PRE. Krull (2004) finds that MNCs increase amounts designated as PRE, thereby deferring recognition of the repatriation tax expense, in order to maximize reported after-tax earnings and meet earnings benchmarks. Graham et al. (2011) report that the extent to which MNCs utilize the PRE designation is positively associated with how important they rate expense deferral and negatively associated with how important they rate cash tax deferral. Evidence from both studies suggests that deferral of the repatriation tax expense is an important motivation in the decision to use the Indefinite Reversal Exception.

\section{Hypotheses}

As we discuss in the "Repatriation and Tax Law" section, existing research finds evidence that repatriation taxes deter repatriation. To examine whether reporting incentives also deter repatriation, we identify and measure firm attributes across which reporting incentives vary while holding the cash payment for repatriation taxes constant. Because the purpose of our study is to explain a continuous accumulation of funds abroad, we use measures that are designed to capture a type of firm that faces either greater capital market pressure to consistently report strong earnings or

\footnotetext{
${ }^{3}$ FASB ASC 740 (2009) contains both the general rule requiring MNCs to recognize an expense for expected repatriation taxes and the Indefinite Reversal Exception.
} 
a greater potential to experience an earnings decrease when repatriating. We do not include measures that capture incentives to time expense recognition, such as variables that capture incentives to beat an earnings benchmark in a specific period, because the timing of repatriations from one year to the next likely represents small differences in overall repatriations that cannot explain an accumulation of funds abroad. With this purpose in mind, we characterize our measures of reporting incentives as capital market measures that capture an anticipated negative capital market response to the repatriation tax expense or as earnings measures that reflect a firm's potential for experiencing an earnings decrease when repatriating.

We begin by investigating hypotheses on whether capital market incentives deter repatriation. We first use public versus private firm ownership as a measure of the anticipated negative capital market response to the repatriation tax expense. This capital market measure allows reporting incentives to vary while holding the cash payment for repatriation taxes relatively constant because both public and private firms are subject to the same tax laws, but capital market pressures vary between public and private firms due to differences in the constituents to which the two types of firms report. Specifically, public firm managers have private information, report to current and potential investors, and are evaluated on their performance based on the information they provide. Therefore, public firm managers typically have a strong focus on reported earnings because of its effect on both firm value and managerial compensation (e.g., Cloyd et al. 1996; Penno and Simon 1986). In contrast, private firms have high levels of insider ownership and encounter less information asymmetry between managers and investors. Therefore, private firm managers have relatively less incentive to focus on reported earnings (Beatty and Harris 1999).

Several studies empirically test this conjecture. Using survey evidence, Penno and Simon (1986) find that public firms are more likely than private firms to choose financial accounting methods that increase earnings. Consistent with this evidence, Cloyd et al. (1996) and Badertscher et al. (2011) find that public firms are more likely than private firms to choose financial accounting methods and/or tax-planning methods that result in higher earnings on the financial statements. The results of these studies suggest that public firms place a stronger focus on increasing accounting earnings than private firms. More closely related to our study, Graham et al. (2011) find that more public firms than private firms rate the financial statement expense for repatriation taxes as important in the repatriation decision. All else equal, we expect that the potential recognition of a repatriation tax expense will have a more negative impact on public firm repatriations than private firm repatriations.

Both the cash payment for repatriation taxes and the financial statement expense for repatriation taxes depend on the repatriation tax rate. Therefore, after controlling for other determinants of repatriation, if public firms are more sensitive to the repatriation tax rate than private firms, then we can attribute this incremental sensitivity to reporting incentives.

H1A: Ceteris paribus, repatriation by public firms is more sensitive to the repatriation tax rate than repatriation by private firms.

Because unobservable differences between public and private firms may affect the sensitivity of repatriation to tax costs, we develop another measure of the anticipated negative capital market response to repatriation tax expense to exploit cross-sectional variation in reporting incentives among public firms. This measure identifies public firms for which we expect a repatriation tax expense to have a more negative effect on firm value. This test focuses on the potential stock price response to a repatriation tax expense as an alternative capital market measure of reporting incentives.

The existing capital markets literature develops many measures that capture various aspects of a potential stock price response to the firm's accounting earnings. Because the purpose of this study is to explain a continuous accumulation of funds outside the U.S., we select three of these measures 
to capture a diverse set of factors that create consistent pressure to report strong earnings numbers: earnings response coefficients, the firm's history of meeting analyst forecasts, and ownership by dedicated institutions.

The first measure is the firm's long-window earnings response coefficient (ERC). The ERC is "the most common empirical measure of investor responsiveness" to earnings (Dechow et al. 2010). We use this variable to capture the extent to which the manager is more likely to believe that tax expense recognition will negatively impact stock price. ${ }^{4}$ As ERCs increase, a firm's pricesensitivity to a repatriation tax expense increases.

The second measure is the proportion of all previous quarters that a firm appears in $\mathrm{I} / \mathrm{B} / \mathrm{E} / \mathrm{S}$ for which it beat the median analyst EPS forecast by one cent or less (Carter et al. 2007; Degeorge et al. 1999). Prior studies find that firms enjoy a stock market premium that increases in their tendency to meet analyst expectations, creating situations in which managers act as if sustaining these patterns will prevent a negative capital market response (e.g., Degeorge et al. 1999; Abarbanell and Lehavy 2003). Tax expense recognition upon repatriation of foreign earnings can cause a firm to miss an analyst forecast, resulting in a reversal of this premium. Therefore, firms with a more consistent history of meeting earnings forecasts are likely to have a higher price-sensitivity to a repatriation tax expense.

The third measure of the potential stock price response to a repatriation tax expense is the proportion of the firm's stock held by long-term institutional investors (Bushee 1998). Bushee (1998) classifies institutional investors based on the extent to which they likely influence myopic behavior by firm managers. Dedicated investors alleviate pressures for myopic behavior (e.g., reducing $\mathrm{R} \& \mathrm{D}$ or repatriations to meet earnings goals) because their large, long-term holdings create incentives to monitor managers and rely on information other than earnings to assess performance. As dedicated investor ownership increases, the firm will likely experience a lower price-sensitivity to expense recognition because investors, and therefore managers, focus less on short-term earnings and more on longer term economic consequences of current period decisions.

Assuming managers want to maximize the firm's stock price, we expect that firms whose stock price will decrease more per dollar of expense will be more sensitive to a repatriation tax expense. Firms with higher ERCs, more consistent histories of beating analyst forecasts, or lower ownership by dedicated institutions face a potentially larger decrease in stock price per dollar of repatriation tax expense. We expect that this higher price-sensitivity to earnings will make these firms' repatriation decisions more sensitive to the repatriation tax rate. Therefore we predict the following:

H1B: Ceteris paribus, repatriation by public firms with high price-sensitivity to earnings is more sensitive to the repatriation tax rate than repatriation by other public firms.

Next, we investigate whether earnings incentives deter repatriations. This test uses a measure that identifies firms for which the earnings effect of repatriations is expected to be relatively high. We identify the extent to which each public MNC in our sample relies on the Indefinite Reversal Exception by obtaining PRE disclosed in financial reports. This test also focuses on public firms because we can only observe PRE disclosures from Securities and Exchange Commission (SEC) filings.

We use PRE to measure reporting incentives to defer repatriations because the cash payment for repatriation taxes is independent of the firm's level of PRE, but the financial statement expense varies directly with the level of PRE. Thus, a firm's level of PRE is a direct measure of the potential financial reporting consequence of repatriation. All else equal, the firm's unrecognized repatriation tax expense increases in PRE. Therefore, MNCs with high amounts of PRE have a greater potential

\footnotetext{
${ }^{4}$ See Kothari (2001) and Dechow et al. (2010) for a review of research in this area.
} 
to recognize a tax expense upon repatriation than firms with low amounts of PRE. Even if an MNC only repatriates current earnings, if it previously designated high levels of undistributed foreign earnings as PRE, then, all else equal, it will have a higher tax expense and lower earnings compared to prior periods. Furthermore, MNCs that have designated all of their undistributed foreign earnings as PRE cannot avoid tax expense recognition in their financial statements by repatriating non-PRE foreign retained earnings while firms with low or no PRE can. ${ }^{5}$

Thus, we expect that firms repatriate less as the unrecognized repatriation tax expense related to the firm's PRE increases. As in our tests of H1A and H1B, if after controlling for other determinants of repatriation, repatriation by firms that use PRE extensively is more sensitive to the repatriation tax rate than other firms, then we can attribute this incremental sensitivity to reporting incentives. Hence, we test the following hypothesis:

H2: Ceteris paribus, repatriation by public firms that rely extensively on the PRE designation under the Indefinite Reversal Exception is more sensitive to the repatriation tax rate than repatriation by other public firms.

\section{DATA}

Examining whether reporting incentives affect the repatriation decisions of MNCs necessitates measuring repatriations, the repatriation tax rate, and reporting incentives. We obtain repatriation amounts and data required to estimate the repatriation tax rate from the Survey of U.S. Direct Investment Abroad conducted by the Bureau of Economic Analysis (BEA) each year since 1982. Federal law obligates MNCs to report certain financial and operating data for both domestic and foreign operations to the BEA. An MNC is the combination of a single U.S. entity, called the U.S. parent, and at least one foreign affiliate. The amount of information collected by the BEA varies by year and by affiliate because more detailed information is collected in benchmark years, which occur every five years (1999 and 2004 in our sample), and only affiliates that meet the applicable reporting threshold are required to report. ${ }^{6}$

MNCs report to the BEA on a fiscal-year basis and follow U.S. Generally Accepted Accounting Principles (GAAP) except consolidation rules. The BEA requires that the U.S. parent use the equity method of accounting for its foreign affiliates, whereas GAAP requires consolidation for ownership interests greater than 50 percent. This unique feature of the data allows us to separately identify foreign and domestic financial data (e.g., foreign assets), which is necessary to

\footnotetext{
${ }^{5}$ Suppose that there are two U.S. multinational firms (A and B) and each has $\$ 900$ of unremitted foreign earnings and pays $\$ 100$ of foreign taxes. In addition, both firms earn $\$ 650(\$ 1,000)$ after-tax (pre-tax) domestically. Upon repatriation of the earnings to the U.S., each firm will have a $\$ 250$ repatriation tax liability. Assume that Firm A always asserts that its unremitted foreign earnings are PRE, whereas Firm B never makes this assertion. Under these facts, Firm A has an effective tax rate (ETR) of 22.5 percent (450/2000) whereas Firm B has an ETR of 35 percent $[(450+250$ (accrued repatriation expense) $) / 2000]$. When earnings are repatriated in a subsequent period, Firm A will recognize an additional \$250 tax expense but Firm B will not. As a result, Firm A's ETR will be higher than 22.5 percent, whereas Firm B will continue to have a 35 percent ETR. In addition, if at any point in the future Firm A ceases making the PRE designation (perhaps because it intends to repatriate current earnings), then its ETR will increase as compared to prior years. Notice that as a firm's PRE increases, the potential earnings impact of repatriation increases. Said another way, the more PRE a firm has, the less flexibility it has to repatriate without an unfavorable change in its ETR.

${ }^{6}$ In order to reduce the reporting burden, the BEA only requires affiliates to participate if its assets, sales, or net income (loss) exceed the threshold for the year. The thresholds are higher in non-benchmark years, thus requiring fewer affiliates to report. Thresholds are \$7 million in 1999, \$30 million in 2000-2003, and \$10 million in 2004. During the 2000-2003 non-benchmark years, most of the financial and operating data that we observe for affiliates that are not required to participate in the survey are estimated by the BEA. We use only reported data, not estimated data, in our analyses.
} 
compute many of our regression variables. The BEA data also enable us to aggregate financial data across the U.S. parent and its foreign affiliates to compute firm-level variables (e.g., worldwide assets). To avoid double-counting, we eliminate intercompany accounts (e.g., assets, sales, and income) reported by the MNC to the BEA. ${ }^{7}$

We combine BEA data with other data sources to construct measures of reporting incentives. Specifically, we determine public versus private ownership status for our sample of BEA firms using Compustat and the LexisNexis Corporate Affiliations database. ${ }^{8}$ For tests that feature only public firms, we calculate ERCs using CRSP data, the percentage of quarters the firm beat analyst forecasts using I/B/E/S data, and dedicated institutional ownership using the Bushee (1998) classification. We obtain PRE from SEC filings.

Table 1, Panel A describes our sample selection process. To construct our sample, we identify MNCs that appear in the BEA data and have at least one foreign affiliate reporting for six consecutive years from 1999 through 2004. These restrictions limit our sample to MNCs with significant foreign operations and create a time period that includes two benchmark years. A total of 4,840 MNCs (57,164 affiliates) appear at least once in the BEA data from 1999 to 2004. Of these, only 805 MNCs (33,196 affiliates) have at least one affiliate reporting in all six years. We further restrict the sample by eliminating ADRs and foreign incorporated parents that are not likely to be constrained by either U.S. tax law or U.S. financial reporting rules when paying dividends to U.S. entities; we also eliminate banks and utilities. ${ }^{9}$ Finally, we eliminate pass-through entities (e.g., partnerships, LLCs, and REITS) since they are typically not subject to corporate income taxes. Our final sample consists of 577 MNCs (25,459 affiliates); 479 MNCs (23,669 affiliates) are public and 98 MNCs (1,790 affiliates) are private. From this balanced panel, we eliminate 285 firm-years for which we do not have all required regression variables for our multivariate analyses resulting in 3,177 firm-years. Table 1, Panel B suggests that broad industry representation is present in our sample, with a heavy emphasis on textiles, manufacturing, and retail.

\section{RESEARCH DESIGN}

Our hypotheses predict that firms are more sensitive to the repatriation tax rate in the presence of reporting incentives. We test our hypotheses by empirically estimating annual repatriations as a function of the estimated repatriation tax rate, a proxy for reporting incentives, an interaction term, and economic incentives to repatriate as follows:

$$
\begin{aligned}
\text { Repatriations }= & \beta_{0}+\beta_{1} \text { RepTR }+\beta_{2} \text { Reporting Incentives }+\beta_{3} \text { Reporting Incentives } \times \text { RepTR } \\
& +\sum \beta_{k} \text { Controls }_{k}+\sum \beta_{t} \text { Year }_{t}+\sum \beta_{j} \text { Industry }_{j}+\varepsilon
\end{aligned}
$$

where:

\footnotetext{
${ }^{7}$ For example, under the equity method of accounting used for BEA reporting, total assets of the U.S. parent includes the "net assets" of its foreign affiliates. However, this amount is reported as a separate line item on the balance sheet of the U.S. parent, allowing us to eliminate intercompany assets without introducing measurement error in our calculation of worldwide assets. For our sample of public firms, the correlation between worldwide assets using Compustat data and worldwide assets using BEA data is $0.98(\mathrm{p}<0.01)$, and for net income the correlation is $0.99(\mathrm{p}<0.01)$. Our repatriations measure only captures dividends paid to the U.S. parent directly from a foreign affiliate, which avoids a double-counting problem with this variable.

${ }^{8}$ We identify public companies in the BEA data by matching with Compustat on company name and verifying private ownership using the LexisNexus Corporate Affiliations database.

${ }^{9}$ Firms operating in these industries are likely to have more opportunities to avoid repatriation taxes by redeploying capital around the world, and they face different incentives than other firms because they are regulated. As a practical matter, we are also unable to compute many of our regression variables for banks because the BEA collects substantially less data for these entities than for other entities because they report to other government agencies.
} 


\section{TABLE 1}

\section{Sample Composition}

\section{Panel A: Bureau of Economic Analysis}

In BEA data between 1999 and 2004

\begin{tabular}{rr} 
Affiliates & Parents \\
57,164 & 4,840 \\
$(12,709)$ & $(2,283)$ \\
$(11,259)$ & $(1,752)$ \\
$(519)$ & $(22)$ \\
$(1,399)$ & $(48)$ \\
$(3,433)$ & $(65)$ \\
$(409)$ & $(10)$ \\
$(1,126)$ & $(61)$ \\
$(147)$ & $(8)$ \\
$(704)$ & $(14)$ \\
\hline 25,459 & 577 \\
1,790 & 98 \\
23,669 & 479
\end{tabular}

Less parents without 6 consecutive years of data

Less parents without 6 consecutive years of affiliate reporting

Less ADRs

Less foreign incorporated parents

Less banks and insurance companies

Less public entities not in Compustat for 6 consecutive years

Less firms missing BEA data

Less firms whose parents cannot be identified ${ }^{\mathrm{a}}$

Total

Private Entities

23,669

\section{Panel B: Industry Composition of Sample}

1. Mining and construction

\begin{tabular}{c} 
Private \\
\hline Combined \\
$10.2 \%$ \\
$13.3 \%$ \\
$10.2 \%$
\end{tabular}

Public

2. Food

3. Textiles, printing, and publishing

$4.4 \%$

4. Chemicals

5. Pharmaceuticals

6. Extractive industries

Combined

$12.1 \%$

$8.4 \%$

$7.1 \%$

$2.3 \%$

7. Durable manufacturing

$22.5 \%$

$5.0 \%$

8. Computers

$5.1 \%$

$25.5 \%$

9. Transportation

$5.1 \%$

$12.1 \%$

$13.3 \%$

$5.4 \%$

11. Retail

13. Insurance and real estate

Combined

14. Services

15. Other and combined low reporting industries ${ }^{\mathrm{b}}$

$7.1 \%$

$16.5 \%$

${ }^{a}$ Includes four mutual companies, four firms that changed status during the sample period (i.e., public to private, foreign ownership to domestic ownership) and six firms whose parents we could not identify as domestic or foreign owned.

b Any industries with less than five observations are combined with the "Other" category.

Repatriations $=$ current-year repatriations scaled by worldwide assets;

RepTR $=$ estimate of the rate of tax the firm would owe to the U.S. if it repatriated all undistributed foreign earnings, computed as the U.S. statutory tax rate (35 percent) minus Creditable Tax Rate ${ }^{10}$ and

Reporting Incentives $=1$ for firms that face relatively high reporting incentives, and 0 otherwise.

\footnotetext{
${ }^{10}$ See Appendix A for a detailed definition of this variable. This measure improves upon existing estimates of the incremental taxes due upon repatriation that use current period foreign tax rates because it is estimated in a manner similar to the U.S. foreign tax credit computation under Section 902 of the Internal Revenue Code. A detailed example of this calculation is available from the authors.
} 
See Appendix A for definitions of all other variables.

We estimate Equation (1) at the firm level because the variables of interest, RepTR and Reporting Incentives, are firm-level constructs. We use a Tobit model for this estimation because roughly 55 percent of the observations in our sample exhibit Repatriations of $0 .{ }^{11}$ RepTR is a measure of the firm's repatriation tax rate. Consistent with existing literature, we expect a negative coefficient on RepTR. For our hypotheses, our focus is on the interaction between RepTR and Reporting Incentives that tests whether repatriation is more sensitive to the repatriation tax rate in the presence of reporting incentives.

We use three proxies for reporting incentives-Public, CapMkt, and HighPre. Our test of H1A uses Public, which equals 1 for firms with public equity, 0 otherwise. ${ }^{12}$ Our test of H1B requires that we identify a sample of public firms with a high price-sensitivity to earnings. Since all public firms face some degree of capital market pressure from various sources that create this sensitivity, we construct a composite measure that allows us to simultaneously consider multiple sources of capital market pressure: (1) investor responsiveness to earnings, estimated using earnings response coefficients (hereafter, $E R C$ ); (2) pressure to beat analyst forecasts, estimated by the proportion of quarters that the firm appears in $\mathrm{I} / \mathrm{B} / \mathrm{E} / \mathrm{S}$ for which it beat the median analyst EPS forecast by one cent or less (hereafter, BEAT); and (3) the likelihood of investor-induced myopic behavior of managers, estimated by the proportion of stock owned by dedicated institutions (hereafter, $D E D) .{ }^{13}$ CapMkt equals 1 for firms with an $E R C$ in the top quartile of the sample, BEAT in the top quartile, or $D E D$ in the bottom quartile, 0 otherwise. ${ }^{14}$ This approach increases the power of our test while allowing us to maintain a sufficient number of observations in both high $(C a p M k t=1)$ and low $($ CapMkt $=0)$ reporting incentive subsamples.

To test $\mathrm{H} 2$ we must identify a subsample of public firms with the most significant unrecognized repatriation tax expense and therefore the greatest potential earnings effect of repatriation. We identify these firms by setting HighPre equal to 1 if PRE equals or exceeds total assets in low-tax affiliates (i.e., affiliates with Affiliate Creditable Tax Rate, defined in Appendix A, less than or equal to 30 percent) in either 1999 or 2004 , and 0 otherwise. ${ }^{15}$

${ }^{11}$ Tobin (1958) originally introduced the Tobit model in the context of censored data, i.e., where data on the dependent variable are lost (or limited) but data on the independent variables are not. Since the seminal work of Tobin, econometricians have clarified that the Tobit model is also appropriately used to analyze "corner solutions," a data structure similar to censored data where the dependent variable takes on the value of zero for a significant proportion of the sample (Wooldridge 2002; Greene 2003). Note that in the corner solution setting, the issue is not the inability to observe data. Numerous public finance economists have used the Tobit model in the context of repatriations (e.g., Hines and Hubbard 1990; Altshuler and Newlon 1993).

${ }^{12}$ Note that we eliminate less than ten MNCs in the BEA data that have public debt but not public equity as it was unclear whether these firms should be classified as public or private firms.

${ }^{13}$ To estimate ERCs, we measure the relation between accounting earnings and security returns using the association, or long-window, approach (e.g., Collins and Kothari 1989; Kormendi and Lipe 1987). Chaney and Jeter (1992) document that long-window rather than short-window ERCs better measure this relation for large firms because there is a greater flow of nonaccounting information between releases of earnings reports.

${ }^{14}$ While this measure incorporates multiple reasons a firm might face capital market pressure into a single variable and therefore captures more information about reporting incentives, it places equal weight on each variable, potentially introducing measurement error. To address this potential, we report results using each component of CapMkt separately in the "Earnings Measures of Reporting Incentives" section.

${ }^{15}$ Scaling PRE by assets in low-tax affiliates assumes that all PRE is in low-tax affiliates. In sensitivity tests we scale PRE by total foreign assets, which assumes that PRE is allocated proportionately across high- and low-tax affiliates. Our results are not sensitive to scaling PRE by total foreign assets or other definitions of this variable as discussed in the "Earnings Measures of Reporting Incentives" section. We use benchmark years (1999 and 2004) to define HighPre because MNCs disclose PRE at the firm-level in SEC filings, but report foreign assets at the affiliate-level in BEA data. More affiliates report in benchmark years because BEA reporting thresholds are lower in those years (described in Section III). Using only benchmark years to define PRE allows us to compare a firm-level variable to the most comprehensive estimate of foreign assets. Since the use of PRE is highly persistent, i.e., firms seldom report decreases in PRE, we identify firms that use PRE extensively as those that meet this threshold in either 1999 or 2004. 
Three factors motivate our definition of HighPre. First, we assume that most PRE relates to activity in low-tax affiliates. Firms have no clear motivation for invoking the PRE designation for foreign earnings that they do not expect to generate a repatriation tax expense upon repatriation. Therefore, as PRE increases relative to assets in low-tax affiliates, the likelihood that a firm can repatriate without recognizing a repatriation tax expense decreases. Second, using a high threshold as a benchmark to construct an indicator variable, rather than using a continuous measure of PRE, ensures that repatriation will have an earnings effect for the subsample of firms we label HighPre. Firms with some undistributed foreign earnings that are not PRE have the ability to repatriate with no earnings effect. ${ }^{16}$ Third, PRE technically arises from basis differences for book and tax purposes; a significant proportion of basis differences arise from undistributed foreign earnings, but these differences can arise from other sources such as the purchase of an affiliate that results in different book and tax bases in the firm's stock. Using assets allows for the possibility that some PRE arises from basis differences other than foreign retained earnings. ${ }^{17}$

Because public firms (i.e., Public $=1$ ) face greater capital market pressure than private firms, public firms with high price-sensitivity to earnings (i.e., CapMkt $=1$ ) face a more negative stock price response to a dollar of a repatriation tax expense than other public firms, and public firms with high amounts of PRE (HighPre $=1)$ deferred recognition of more repatriation tax expense. H1A, $\mathrm{H} 1 \mathrm{~B}$, and $\mathrm{H} 2$ predict that repatriation by these firms is more sensitive to the repatriation tax rate than repatriation by other firms. All else equal, we expect negative coefficients on Public $\times$ RepTR, CapMkt $\times$ RepTR, and HighPre $\times$ RepTR.

In addition to our variables of interest, we include controls for other factors that influence repatriation decisions. First, we include controls for investment opportunities abroad and in the U.S. (Foreign ROA and U.S. ROA, respectively). Hartman (1985) argues that firms will invest earnings in operations with the highest after-tax return by repatriating only when the after-tax return on foreign investment is less than the after-tax return on domestic investment. This theoretical result suggests that repatriations are negatively related to foreign investment opportunities and positively related to domestic investment opportunities. However, firms with more profitable foreign operations have more funds available to repatriate, suggesting a positive coefficient on Foreign $R O A$. Likewise, firms with profitable domestic operations have more domestic funds available for investment in the U.S., suggesting a negative coefficient on U.S.ROA. Thus, we make no prediction for the coefficients on U.S. ROA or Foreign ROA. ${ }^{18}$

We include Indirect Ownership and Holding Company to control for cross-sectional variation in the sophistication of firms' international tax-planning strategies. These variables control for a potential self-selection problem with respect to Public and HighPre. Specifically, evidence exists that public and private firms face different financial and tax reporting trade-offs that affect the type and amount of tax planning they undertake. For example, Beatty and Harris (1999) and Mikhail (1999) find evidence that private firms are more aggressive tax planners than public firms. In addition, Hanlon et al. (2007) link private ownership to greater proposed income tax deficiencies with the IRS than public ownership. Further, some firms may designate foreign earnings as PRE because they are invested in sophisticated tax-planning strategies. These relationships could bias the

\footnotetext{
${ }^{16}$ See footnote 5 for a specific example.

${ }^{17}$ The Indefinite Reversal Exception applies broadly to outside basis differences, i.e., differences in the book and tax bases of a firm's stock in its affiliate (BNA 2010). Many outside basis differences have potential U.S. tax consequences upon repatriation but are not reflected in retained earnings. Therefore, assets better captures the broader concept of PRE than retained earnings.

${ }^{18}$ Hartman (1985) suggests that the difference between these two variables, U.S. ROA - Foreign ROA, should be included as an explanatory variable. We include them separately, which is similar to including the difference but allows the coefficients on the two variables to differ.
} 
coefficients on Public $\times$ RepTR and HighPre $\times$ RepTR up or down depending on the effect of tax planning on repatriations.

Sophisticated tax planning will increase repatriations if the strategy allows for tax-efficient repatriation. For example, Altshuler and Grubert (2003) describe strategies that allow the U.S. parent to effectively convert income earned in low-tax affiliates into high-tax income that can be repatriated tax free. Conversely, tax planning will decrease repatriations if the strategy calls for long-duration foreign investment projects to defer the U.S. tax liability (Desai et al. 2003). The strategies described in Altshuler and Grubert (2003) and Desai et al. (2003) use tiered-ownership in which the parent indirectly owns a foreign affiliate through another foreign affiliate. These strategies also use indirect ownership of a foreign affiliate through a holding company, which is an affiliate that does not produce goods or services, but is created solely to own another affiliate. Thus, we control for the sophistication of a firm's tax planning using two measures of the extent to which the firm uses tiered-ownership. Following Desai et al. (2003), we define Indirect Ownership as the proportion of the firm's foreign affiliates that are indirectly owned. Similarly, we define Holding Company as the proportion of the firm's foreign affiliates that are holding companies (i.e., those with North American Industry Classification System code 5512). Because these tax-planning strategies can increase or decrease repatriations, we do not make a sign prediction for these variables.

Equation (1) also includes controls for the size of foreign operations, agency costs, financing constraints, and costs of financing. Size equals the natural log of foreign sales. We expect a positive coefficient on Size because firms with larger foreign operations have more funds available to repatriate. We include U.S. Leverage and Foreign Leverage to control for firms' debt service needs and capital structure. Firms may be more reluctant to repatriate if they have high foreign debt service, suggesting a negative association between Foreign Leverage and repatriations. We do not make a prediction for U.S. Leverage because two opposing forces influence its relation with repatriations. U.S. Leverage will be positively associated with repatriations if firms distribute funds to service domestic debt. Alternatively, U.S. Leverage will be negatively associated with repatriations if domestic debt is used as a substitute for cash from repatriations, or if firms borrow domestically against undistributed foreign earnings.

We include U.S. Interest Rate, the interest rate on domestic debt, to control for the domestic cost of borrowing. We anticipate that firms with a higher cost of borrowing in the U.S. have higher repatriations. We include Foreign Interest Rate, the interest rate on foreign debt, to control for the foreign cost of borrowing. We expect that firms with a higher cost of borrowing abroad repatriate less. \%Foreign Assets controls for the size of foreign operations relative to the size of the firm and we expect a positive coefficient on \%Foreign Assets. We include U.S. Loss because Altshuler and Newlon (1993) and Power and Silverstein (2007) find that firms with a domestic net operating loss (NOL) are less likely to repatriate because repatriations convert domestic NOLs into foreign tax credits (FTCs). ${ }^{19}$ U.S. MNCs are reluctant to give up the NOL in exchange for an FTC because the FTC has a shorter carryforward period.

Finally, we include four measures to control for country-level factors that affect repatriations. We first determine each country-level measure at the affiliate level, and then we calculate the parent-level score as the average of the affiliate scores. Mandatory Dividend equals 1 if the country requires dividends to be paid to shareholders, and 0 otherwise (La Porta et al. 1998). Corruption is

\footnotetext{
${ }^{19}$ Repatriation by a firm with a domestic NOL does not incur a repatriation tax because the NOL offsets the taxable income generated by the repatriation. However, because there is no current U.S. tax liability, U.S. tax law does not permit the firm to use any FTC associated with the repatriation, but instead requires it to create a FTC carryforward. Thus, when a firm with a NOL repatriates foreign earnings, ordering rules require it to use some of its NOL and create a FTC carryforward.
} 
an index taking values from 1 through 10, with 10 representing the lowest level of corruption (La Porta et al. 1998). Corruption will decrease repatriations if it increases the cost of doing business such that more capital must remain in the country; alternatively corruption may increase repatriations to reduce the probability of expropriation or theft. Infrastructure is an index taking values of 1 through 10, with 10 representing the most developed infrastructure (La Porta et al. 1999). All else equal, the less developed a country's infrastructure, the more capital the company likely needs to invest in its operations. Finally, Capital Control is equal to 1 if the country restricts a firm's ability to take funds out of the country, and 0 otherwise (International Monetary Fund [IMF] 2006).

\section{RESULTS}

\section{Descriptive Statistics}

Table 2 provides descriptive statistics for our BEA sample. We report all statistics at the firm level unless otherwise noted and show statistics separately for private firms, low PRE public firms $($ HighPre $=0)$, and high PRE public firms $($ HighPre $=1)$. We winsorize all continuous measures at the top and bottom 1 percent and truncate all tax rate measures to fall between 0 and 100 percent. Finally, due to confidentiality restrictions, reported medians (Med5) represent the mean of the five middle observations.

Table 2, Panel A reports descriptive statistics for the variables in Equation (1). As expected, public and private firms exhibit several notable differences. Public firms have more extensive foreign operations that are larger overall (mean Size equals 13.50 for private firms, 14.74 for low PRE Public firms, and 15.14 for high PRE public firms), and they engage in more sophisticated tax planning (mean Indirect Ownership and Holding Company are 11.14 and 2.26 for private firms, 19.35 and 5.11 for low PRE public firms, and 24.92 and 7.02 for high PRE public firms). While Foreign Leverage is similar across the three subsamples, public firms have significantly higher U.S. Leverage than private firms. This difference likely results because, per our definition of Public, public firms in our sample can have public debt, while private firms cannot and existing research shows that firms with public debt have, on average, 35 percent more debt than firms with only private debt (Faulkender and Petersen 2006). Our multivariate tests control for these differences across public and private firms.

Within the sample of public firms, approximately 19 percent (506 observations) have HighPre equal to 1. Interestingly, Repatriations are largest for high PRE firms. The spirit of the Indefinite Reversal Exception, requiring firms to declare that foreign earnings are indefinitely invested abroad, suggests that high PRE firms might exhibit smaller Repatriations than other firms. However, HighPre is measured as a proportion of assets that are not repatriated. Therefore, high PRE firms can have higher repatriations, on average, but designate a greater proportion of earnings that are not repatriated as PRE. This result could arise if high PRE firms have made more profitable investments that generate more income and, in turn, generate more repatriations. It could also arise if high PRE firms are more likely to borrow in the U.S. using foreign assets as collateral and repatriate more foreign earnings to service U.S. debt. Our interest, however, is in whether high PRE firms are more sensitive to the repatriation tax rate than low PRE firms. As with differences across public and private firms, we control for observable differences across high PRE and low PRE firms. To reduce the possibility that unobservable differences drive our results, we use multiple proxies for reporting incentives and conduct a battery of sensitivity tests.

Table 2, Panel B reports descriptive statistics to compare tax rate measures used in existing research. DFH Tax Rate equals the median accounting effective tax rate for all U.S. affiliates operating in a country-year as described in Desai et al. (2001), and Current FTR equals current- 

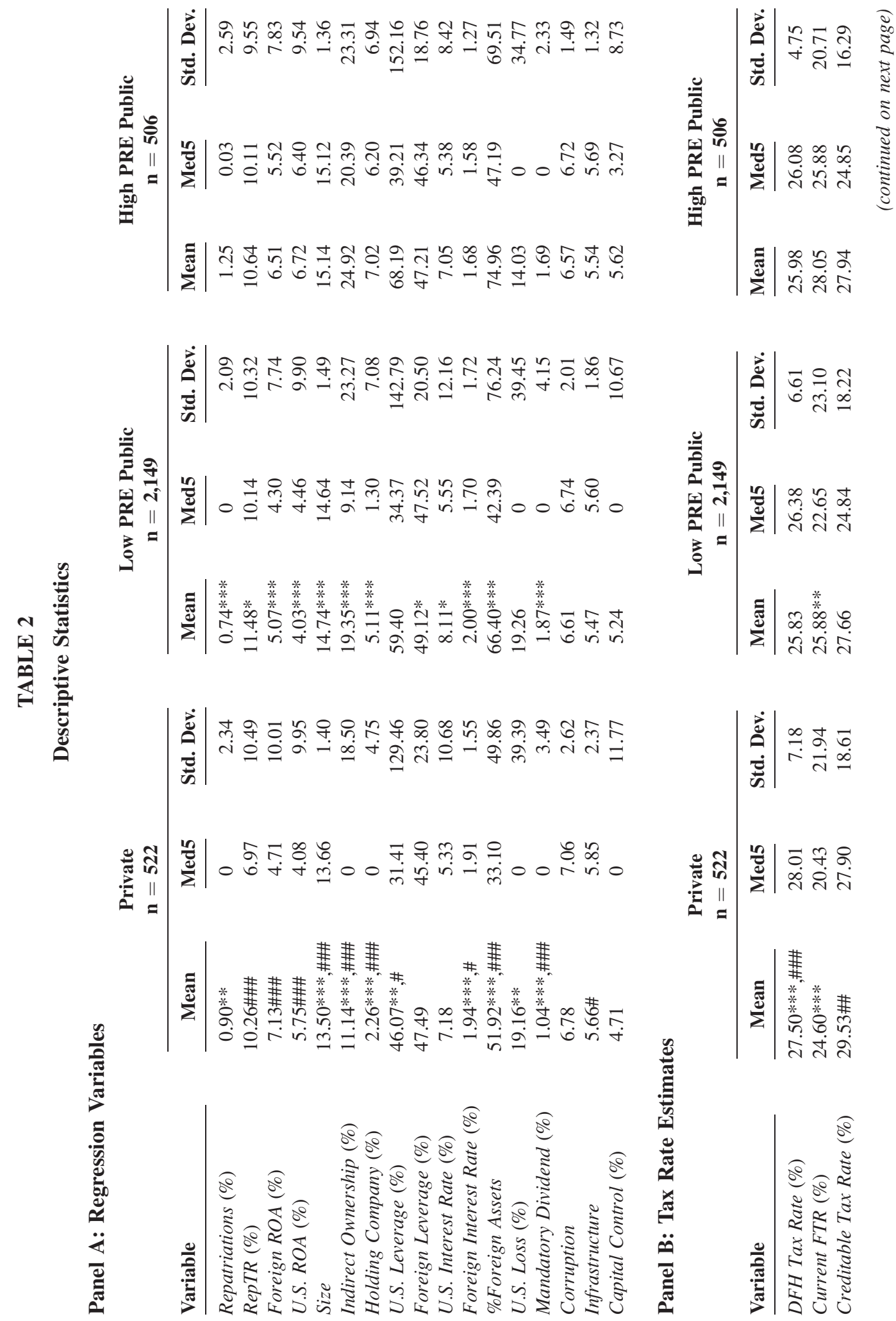


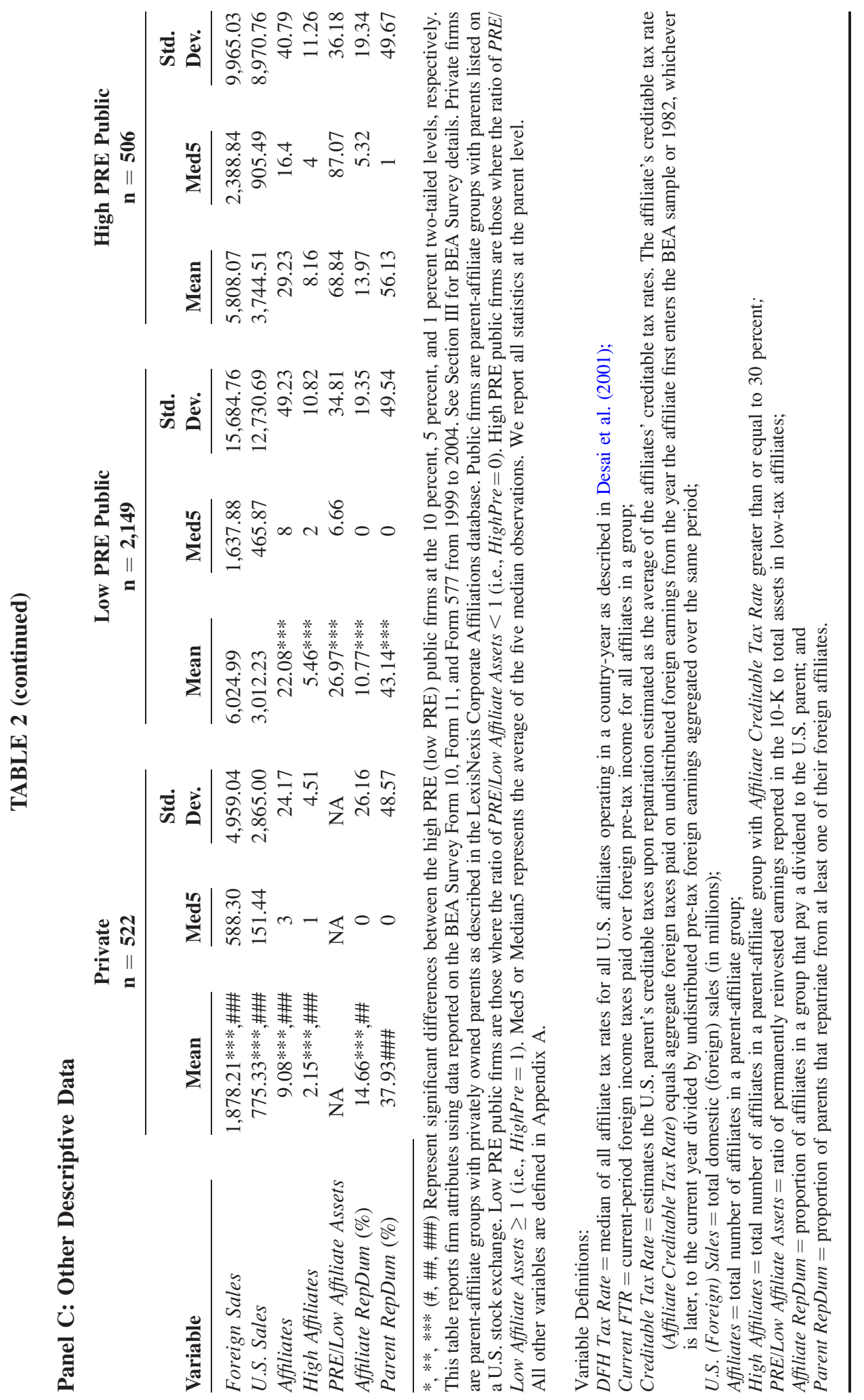


period foreign income taxes paid over foreign pre-tax income. Public firms have a lower DFH Tax Rate than private firms, consistent with survey evidence in Graham et al. (2011) that the benefit of tax expense deferral is of primary importance in investment location decisions of public companies. Consistent with private firms facing higher income tax burdens and lower expected repatriation tax burdens, Creditable Tax Rate is higher for private firms than for both subsamples of public firms. However, Current FTR is lowest for private firms. A low Current FTR but high Creditable Tax Rate suggests that a non-trivial proportion of undistributed earnings were generated in the past when foreign tax rates were relatively higher than the U.S. tax rate. Table 2, Panel C reports general descriptive statistics for the BEA data. Public firms are larger than private firms in terms of number of affiliates and total sales. We control for these differences in our regression analysis.

\section{Capital Market Measures of Reporting Incentives}

Table 3, Column (1) reports the results of estimating Equation (1), excluding a measure of Reporting Incentives, for our sample of 577 public and private firms with necessary data from 1999 through 2004. Column (1a) reports the marginal effects. Consistent with existing literature, the coefficient on RepTR is negative and significant. Table 3, Column (2) reports the results of estimating Equation (1) using Public as a proxy for Reporting Incentives. The coefficient on Public is not significantly different from zero suggesting that, holding the repatriation tax rate constant, public companies are no less likely to repatriate, on average, than private companies. Consistent with H1A, the interaction between Public and RepTR is negative and significant $(-0.0398 ; \mathrm{p}<$ $0.10)$ suggesting that public firm repatriation is more sensitive to the repatriation tax rate than private firm repatriation. $^{20}$

Table 3, Column (2a) reports the marginal effect of each variable on the unconditional expected value of Repatriations, which we use to interpret the coefficient estimates. We calculate the marginal effect of Public $\times$ RepTR using Ai and Norton (2003) and McDonald and Moffitt $(1980) .^{21}$ The marginal effect of Public $\times$ RepTR on the unconditional expected value of Repatriations is -0.0151 . This estimate suggests that the change in Repatriations when RepTR changes from 0 to the sample mean of 0.1115 is 0.168 percent of assets lower for public firms than for private firms. Mean worldwide assets for our sample is $\$ 8.34$ billion. Therefore, the average public firm repatriates $\$ 14$ million $(-0.0151 \times 0.1115 \times \$ 8,344=\$ 14)$, or 3.4 percent of foreign earnings less per year than the average private firm. For our 479 public firms, this figure amounts to $\$ 6.7$ billion in repatriations per year.

The coefficient on U.S. ROA is insignificant while the coefficient on Foreign ROA is positive and significant. These results suggest that firms with more profitable foreign operations have more cash available to repatriate and that this effect outweighs the investment opportunity effect predicted by Hartman (1985). However, for U.S. ROA, the investment opportunity effect is offset by a lower need for cash. Size, Lag Repatriations, U.S. Leverage, Foreign Interest, \%Foreign Assets, and Mandatory Dividend are significant in the expected direction. The positive coefficient on U.S. Leverage suggests that firms repatriate foreign earnings, in part, to service domestic debt while the negative coefficient on Foreign Interest suggests that firms with a higher cost of borrowing abroad repatriate less, in part, to service foreign debt. We interpret the positive

\footnotetext{
${ }^{20}$ Results in Table 3 and Table 4 are robust to scaling repatriations by worldwide sales or worldwide retained earnings. Results in Table 3 and Table 4, Columns (2) and (3) are also robust to using the log of repatriations as the dependent variable.

${ }^{21}$ A detailed discussion of this calculation is available upon request from the authors. This discussion includes an explanation of the McDonald and Moffitt (1980) decomposition of Tobit coefficients, as well as our STATA code for estimating the marginal effects of interaction terms.
} 
TABLE 3

\section{Impact of the Capital Market Measures on Repatriations \\ Dependent Variable $=$ Repatriations}

\begin{tabular}{|c|c|c|c|c|c|c|}
\hline & (1) & (1a) & (2) & (2a) & (3) & (3a) \\
\hline RepTR & $\begin{array}{c}-0.0311 * * * \\
(0.0083)\end{array}$ & -0.0115 & $\begin{array}{c}0.0010 \\
(0.0226)\end{array}$ & 0.0004 & $\begin{array}{c}-0.0220 * * \\
(0.0102)\end{array}$ & -0.0080 \\
\hline Public & & & $\begin{array}{c}-0.0013 \\
(0.0036)\end{array}$ & -0.0005 & & \\
\hline Public $\times$ RepTR & & & $\begin{array}{r}-0.0398^{*} \\
(0.0239)\end{array}$ & -0.0151 & & \\
\hline CapMkt & & & & & $\begin{array}{c}-0.0005 \\
(0.0021)\end{array}$ & -0.0002 \\
\hline CapMkt $\times$ RepTR & & & & & $\begin{array}{c}-0.0350 * * \\
(0.0149)\end{array}$ & -0.0123 \\
\hline Foreign ROA & $\begin{array}{l}0.0751 * * * \\
(0.0130)\end{array}$ & 0.0278 & $\begin{array}{l}0.0723 * * * \\
(0.0129)\end{array}$ & 0.0267 & $\begin{array}{l}0.0849 * * * \\
(0.0144)\end{array}$ & 0.0309 \\
\hline U.S. ROA & $\begin{array}{c}0.0137 \\
(0.0121)\end{array}$ & 0.0051 & $\begin{array}{c}0.0114 \\
(0.0122)\end{array}$ & 0.0042 & $\begin{array}{c}0.0160 \\
(0.0135)\end{array}$ & 0.0058 \\
\hline Size & $\begin{array}{l}0.0049 * * * \\
(0.0006)\end{array}$ & 0.0018 & $\begin{array}{l}0.0052 * * * \\
(0.0006)\end{array}$ & 0.0019 & $\begin{array}{l}0.0056 * * * \\
(0.0007)\end{array}$ & 0.0020 \\
\hline Lag Repatriations & $\begin{array}{l}0.6323 * * * \\
(0.0613)\end{array}$ & 0.2343 & $\begin{array}{l}0.6314 * * * \\
(0.0610)\end{array}$ & 0.2330 & $\begin{array}{l}0.6008 * * * \\
(0.0666)\end{array}$ & 0.2187 \\
\hline Indirect Ownership & $\begin{array}{c}-0.0013 \\
(0.0047)\end{array}$ & -0.0005 & $\begin{array}{c}-0.0011 \\
(0.0047)\end{array}$ & -0.0004 & $\begin{array}{c}-0.0040 \\
(0.0042)\end{array}$ & -0.0014 \\
\hline Holding Company & $\begin{array}{c}-0.0079 \\
(0.0134)\end{array}$ & -0.0029 & $\begin{array}{r}-0.0046 \\
(0.0134)\end{array}$ & -0.0017 & $\begin{array}{c}-0.0015 \\
(0.0129)\end{array}$ & -0.0001 \\
\hline U.S. Leverage & $\begin{array}{c}0.0010 * \\
(0.0006)\end{array}$ & 0.0004 & $\begin{array}{c}0.0011 * \\
(0.0006)\end{array}$ & 0.0004 & $\begin{array}{l}0.0016 * * * \\
(0.0005)\end{array}$ & 0.0006 \\
\hline Foreign Leverage & $\begin{array}{c}-0.0007 \\
(0.0037)\end{array}$ & -0.0003 & $\begin{array}{c}-0.0009 \\
(0.0037)\end{array}$ & -0.0003 & $\begin{array}{c}0.0004 \\
(0.0040)\end{array}$ & 0.0001 \\
\hline U.S. Interest Rate & $\begin{array}{c}0.0029 \\
(0.0071)\end{array}$ & 0.0011 & $\begin{array}{c}0.0038 \\
(0.0073)\end{array}$ & 0.0014 & $\begin{array}{c}0.0030 \\
(0.0075)\end{array}$ & 0.0011 \\
\hline Foreign Interest Rate & $\begin{array}{c}-0.0906 * * \\
(0.0399)\end{array}$ & -0.0336 & $\begin{array}{c}-0.0951 * * \\
(0.0404)\end{array}$ & -0.0351 & $\begin{array}{c}-0.0826 * * \\
(0.0419)\end{array}$ & -0.0300 \\
\hline \%Foreign Assets & $\begin{array}{l}0.0089 * * * \\
(0.0015)\end{array}$ & 0.0033 & $\begin{array}{l}0.0091 * * * \\
(0.0014)\end{array}$ & 0.0034 & $\begin{array}{l}0.0086 * * * \\
(0.0014)\end{array}$ & 0.0031 \\
\hline U.S. Loss & $\begin{array}{c}0.0015 \\
(0.0025)\end{array}$ & 0.0006 & $\begin{array}{c}0.0012 \\
(0.0024)\end{array}$ & 0.0004 & $\begin{array}{c}0.0025 \\
(0.0025)\end{array}$ & 0.0009 \\
\hline Mandatory Dividend & $\begin{array}{l}0.0444 * * \\
(0.0181)\end{array}$ & 0.0165 & $\begin{array}{l}0.0479 * * * \\
(0.0178)\end{array}$ & 0.0177 & $\begin{array}{l}0.0443 * * \\
(0.0201)\end{array}$ & 0.0161 \\
\hline Corruption & $\begin{array}{c}0.0053 \\
(0.0118)\end{array}$ & 0.0020 & $\begin{array}{c}0.0049 \\
(0.0116)\end{array}$ & 0.0018 & $\begin{array}{c}-0.0049 \\
(0.0112)\end{array}$ & -0.0018 \\
\hline Infrastructure & $\begin{array}{c}-0.0121 \\
(0.0137)\end{array}$ & -0.0045 & $\begin{array}{c}-0.0114 \\
(0.0132)\end{array}$ & -0.0042 & $\begin{array}{c}0.0020 \\
(0.0121)\end{array}$ & 0.0007 \\
\hline Capital Control & $\begin{array}{r}-0.0003 \\
(0.0093)\end{array}$ & -0.0001 & $\begin{array}{c}-0.0011 \\
(0.0090)\end{array}$ & -0.0004 & $\begin{array}{c}0.0010 \\
(0.0102)\end{array}$ & 0.0004 \\
\hline Intercept & $\begin{array}{c}-0.0808 * * * \\
(0.0112)\end{array}$ & -0.0299 & $\begin{array}{c}-0.0854 * * * \\
(0.0113)\end{array}$ & -0.0315 & $\begin{array}{c}-0.0945 \\
(0.0117)\end{array}$ & -0.0397 \\
\hline Scale & $\begin{array}{c}0.0274 \\
(0.0016)\end{array}$ & & $\begin{array}{c}0.0274 \\
(0.0016)\end{array}$ & & $\begin{array}{c}0.0259 \\
(0.0016)\end{array}$ & \\
\hline
\end{tabular}

(continued on next page) 


\section{TABLE 3 (continued)}

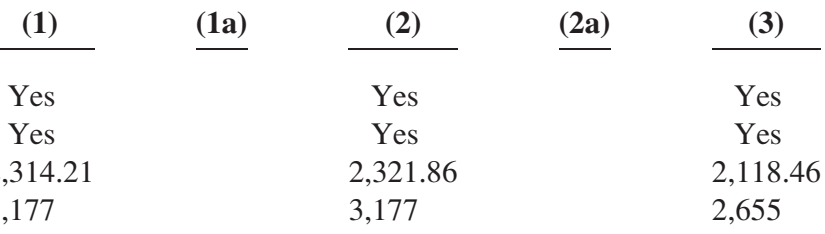

Year Fixed Effects Industry Fixed Effects Log Likelihood $\mathrm{n}$

*, **, *** Significant at the 10 percent, 5 percent, and 1 percent two-tailed levels, respectively. Robust standard errors are reported in parentheses.

Columns (1), (2), and (3) report coefficients from the Tobit estimation. Columns (1a), (2a), and (3a) report the marginal effect of each variable on the unconditional expected value of Repatriations. Details on these calculations are available from the authors. See Appendix A for variable definitions.

coefficient on \%Foreign Assets as suggesting that firms with proportionately greater foreign assets repatriate a greater proportion of total assets.

Table 3, Column (3) reports the results of estimating Equation (1) for our sample of 479 public firms using CapMkt as a proxy for Reporting Incentives. This test reduces the possibility that unobservable differences between public and private firms, such as access to capital, affect the sensitivity of repatriation to tax costs, and instead focuses on cross-sectional variation in capital market pressure among public firms. Recall that CapMkt equals 1 for public firms for which the $E R C$ is in the top quartile of the sample, BEAT is in the top quartile, or DED is in the bottom quartile, 0 otherwise. ${ }^{22}$ Consistent with $\mathrm{H} 2$, the interaction between CapMkt and RepTR is negative and significant $(-0.0350 ; \mathrm{p}<0.05)$ suggesting that repatriation by public firms with a potentially larger stock price response to the repatriation tax expense is more sensitive to the repatriation tax rate relative to repatriation by other public firms. Inferences are similar if we test each condition separately, although only significant for two of the three conditions. If we define CapMkt as equal to 1 for firms in the top quartile of ERC, then the coefficient on CapMkt $\times$ RepTR is -0.0436 (standard error $=0.0174$ ). If we define CapMkt as equal to 1 when BEAT is in the top quartile, then the coefficient on CapMkt $\times$ RepTR is -0.0338 (standard error $=0.0174$ ). If we define CapMkt as equal to 1 if $D E D$ is in the bottom quartile, then the coefficient on CapMkt $\times$ RepTR is -0.0146 $($ standard error $=0.0149){ }^{23}$

The marginal effect of CapMkt $\times$ RepTR on the unconditional expected value of Repatriations is -0.0123 . Mean worldwide assets for our public sample is $\$ 9.62$ billion. Thus, the change in Repatriations when RepTR changes from 0 to the sample mean of 0.1133 is 0.139 percent of assets $(-0.0123 \times 0.1133)$ or $\$ 13.4$ million $(-0.0123 \times 0.1133 \times \$ 9,616=\$ 13.4)$, or 2.8 percent of public firm foreign earnings lower for a firm with high capital market pressure than for a firm with low capital market pressure. This figure amounts to approximately $\$ 2.9$ billion per year for our 1,298 high capital market pressure observations $((\$ 13.4 \times 1,298) / 6)$. In addition, the marginal effect of

\footnotetext{
${ }^{22}$ Mean (median) ERC in our sample is 4.06 (2.67) with a standard deviation of 5.19. The mean (median) of BEAT is 23.5 percent (21.1 percent) with a standard deviation of 18.2 percent. The mean (median) of $D E D$ is 4.5 percent ( 0 percent) with a standard deviation of 7.4 percent. CapMkt equals 1 for 1,298 of the 2,655 observations in the sample of public firms.

${ }^{23} \mathrm{We}$ also examine the robustness of these results to using different measures of BEAT to define CapMkt. Results are consistent when we define BEAT using three cents as a cutoff instead of one cent, using last year's earnings instead of analyst forecasts and both one cent and three cent cutoffs, and using annual instead of quarterly earnings. Results are also consistent if we define BEAT as equal to 1 if the number of consecutive years the firm met analyst forecasts by one cent or less, with a maximum of 5 years, is in the top quartile, similar to Barth et al. (1999). These measures also produce consistent results when we test them separately, except when we use last year's earnings as the benchmark with a three cent cutoff.
} 
Public $\times$ RepTR is larger than the marginal effect of RepTR $(-0.0080)$, consistent with MNCs placing at least as much importance on expense deferral relative to cash tax deferral and with the results in Graham et al. (2011).

\section{Earnings Measures of Reporting Incentives}

Table 4 reports the results of estimating Equation (1) for our sample of 479 public firms using HighPre as our measure of Reporting Incentives. HighPre $\times$ RepTR tests for the effect of reporting incentives on repatriation by examining whether repatriation by public firms that defer recognition of the repatriation tax expense is more sensitive to the repatriation tax rate relative to repatriation by other public firms. Consistent with $\mathrm{H} 3$, the coefficient on HighPre $\times$ RepTR is negative and significant $(-0.0417 ; \mathrm{p}<0.05) .{ }^{24}$ In Column (1a) we report the marginal effects. The marginal effect of HighPre $\times$ RepTR on the unconditional expected value of Repatriations is -0.0160 . Thus, the change in Repatriations when RepTR changes from 0 to the sample mean of 0.1133 is 0.181 percent of assets $(-0.0160 \times 0.1133)$ or $\$ 17.4$ million $(-0.0160 \times 0.1133 \times$ $\$ 9,616=\$ 17.4$ ), or 3.6 percent of public firm foreign earnings lower for a high PRE public firm than for a low PRE public firm. This figure amounts to approximately $\$ 1.5$ billion per year for our 506 high PRE observations $((\$ 17.4 \times 506) / 6)$.

Collectively, our empirical results tell a consistent story in which reporting incentives deter repatriation. First, repatriation by public firms appears to be more sensitive to the repatriation tax rate than repatriation by private firms because public firms place relatively greater focus on accounting earnings. Second, repatriation by public firms that anticipate a more negative stock price reaction to the repatriation tax expense is more sensitive to the repatriation tax rate than repatriation by other public firms. Third, repatriation by public companies that rely extensively on PRE is more sensitive to the repatriation tax rate than repatriation by other public firms. ${ }^{25}$

\section{SUPPLEMENTAL ANALYSES}

\section{Firms with High PRE and High Capital Market Pressure}

As discussed in Section IV, if public firms engage in different types and amounts of tax planning than private firms and/or high PRE firms engage in different types and amounts of tax planning than low PRE firms, then a self-selection problem could bias the coefficients on Public $\times$ RepTR or HighPre $\times$ RepTR up or down depending on the relationship between these taxplanning differences and repatriations. To control for this potential bias, we include Indirect

\footnotetext{
${ }^{24}$ We evaluate the sensitivity of this result using many definitions of HighPre. Results are similar when we define HighPre as equal to 1 when PRE meets the following conditions in a benchmark year (1999 or 2004): the firm's ratio of PRE to total assets in low-tax affiliates is greater than or equal to 95 percent or 80 percent, the ratio of PRE to retained earnings in low-tax affiliates is greater than or equal to 1, 95 percent, or 80 percent, PRE divided by total foreign assets, worldwide assets, or worldwide retained earnings is greater than or equal to the 90th percentile (we use the 90th percentile for these scalars because this ratio is greater than 1 for only a few observations). We also evaluate the use of a continuous measure. Results are similar when we define HighPre as PRE divided by assets in low-tax affiliates, but are not significant when we define HighPre as PRE divided by total foreign assets $(t=-1.54)$.

${ }^{25}$ An alternate interpretation of the negative coefficient on HighPre $\times$ RepTR is that high PRE firms lack the ability to repatriate because they are more heavily invested in operating assets abroad than other firms. We formally rule out this explanation in the "Foreign Cash Holdings" section by showing that, relative to other public firms, the cash holdings of high PRE firms increase more when the repatriation tax rate increases.
} 


\section{TABLE 4}

\section{Impact of the Earnings Effect on Repatriations} Dependent Variable $=$ Repatriations

\begin{tabular}{|c|c|c|c|c|c|c|}
\hline \multirow{3}{*}{ RepTR } & (1) & (1a) & $(2)$ & (2a) & (3) & (3a) \\
\hline & \multicolumn{2}{|c|}{ All Public Firms } & \multicolumn{2}{|c|}{ CapMkt $=1$} & \multicolumn{2}{|c|}{ CapMkt $=\mathbf{0}$} \\
\hline & $\begin{array}{c}-0.0299 * * * \\
(0.0092)\end{array}$ & -0.0109 & $\begin{array}{c}-0.0489 * * * \\
(0.0136)\end{array}$ & -0.0134 & $\begin{array}{r}-0.0136 \\
(0.0117)\end{array}$ & -0.0061 \\
\hline HighPre & $\begin{array}{l}0.0059^{* *} \\
(0.0028)\end{array}$ & 0.0023 & $\begin{array}{c}0.0075 \\
(0.0046)\end{array}$ & 0.0023 & $\begin{array}{c}0.0054 \\
(0.0034)\end{array}$ & 0.0026 \\
\hline HighPre $\times$ RepTR & $\begin{array}{c}-0.0417^{* *} \\
(0.0180)\end{array}$ & -0.0160 & $\begin{array}{r}-0.0576^{*} \\
(0.0307)\end{array}$ & -0.0204 & $\begin{array}{c}-0.0334 \\
(0.0231)\end{array}$ & -0.0133 \\
\hline Foreign ROA & $\begin{array}{l}0.0831 * * * \\
(0.0143)\end{array}$ & 0.0303 & $\begin{array}{l}0.0919 * * * \\
(0.0226)\end{array}$ & 0.0251 & $\begin{array}{l}0.0872 * * * \\
(0.0176)\end{array}$ & 0.0395 \\
\hline U.S. ROA & $\begin{array}{c}0.0121 \\
(0.0133)\end{array}$ & 0.0044 & $\begin{array}{c}-0.0073 \\
(0.0232)\end{array}$ & -0.0020 & $\begin{array}{l}0.0283 * * \\
(0.0142)\end{array}$ & 0.0128 \\
\hline Size & $\begin{array}{l}0.0059 * * * \\
(0.0007)\end{array}$ & 0.0022 & $\begin{array}{l}0.0051 * * * \\
(0.0008)\end{array}$ & 0.0014 & $\begin{array}{l}0.0060^{* * * *} \\
(0.0009)\end{array}$ & 0.0027 \\
\hline Lag Repatriations & $\begin{array}{l}0.6106^{* * * *} \\
(0.0658)\end{array}$ & 0.2228 & $\begin{array}{l}0.6684 * * * \\
(0.1076)\end{array}$ & 0.1828 & $\begin{array}{l}0.5484 * * * \\
(0.0805)\end{array}$ & 0.2486 \\
\hline Indirect Ownership & $\begin{array}{c}-0.0037 \\
(0.0043)\end{array}$ & -0.0013 & $\begin{array}{r}-0.0035 \\
(0.0063)\end{array}$ & -0.0010 & $\begin{array}{r}-0.0036 \\
(0.0062)\end{array}$ & -0.0016 \\
\hline Holding Company & $\begin{array}{c}-0.0018 \\
(0.0133)\end{array}$ & -0.0007 & $\begin{array}{c}0.0073 \\
(0.0259)\end{array}$ & 0.0020 & $\begin{array}{c}-0.0056 \\
(0.0144)\end{array}$ & -0.0026 \\
\hline U.S. Leverage & $\begin{array}{l}0.0017 * * * \\
(0.0006)\end{array}$ & 0.0006 & $\begin{array}{c}0.0005 \\
(0.0008)\end{array}$ & 0.0001 & $\begin{array}{l}0.0022 * * * \\
(0.0007)\end{array}$ & 0.0010 \\
\hline Foreign Leverage & $\begin{array}{c}0.0011 \\
(0.0040)\end{array}$ & 0.0004 & $\begin{array}{c}-0.0039 \\
(0.0061)\end{array}$ & -0.0011 & $\begin{array}{c}0.0050 \\
(0.0052)\end{array}$ & 0.0023 \\
\hline U.S. Interest Rate & $\begin{array}{c}0.0045 \\
(0.0072)\end{array}$ & 0.0016 & $\begin{array}{c}0.0011 \\
(0.0132)\end{array}$ & 0.0003 & $\begin{array}{c}0.0039 \\
(0.0072)\end{array}$ & 0.0018 \\
\hline Foreign Interest Rate & $\begin{array}{c}-0.0813^{* *} \\
(0.0419)\end{array}$ & -0.0297 & $\begin{array}{c}-0.0562 \\
(0.0544)\end{array}$ & -0.0154 & $\begin{array}{c}-0.0866 \\
(0.0564)\end{array}$ & -0.0393 \\
\hline \%Foreign Assets & $\begin{array}{l}0.0084 * * * \\
(0.0014)\end{array}$ & 0.0031 & $\begin{array}{l}0.0079 * * * \\
(0.0018)\end{array}$ & 0.0022 & $\begin{array}{l}0.0091 * * * \\
(0.0023)\end{array}$ & 0.0041 \\
\hline U.S. Loss & $\begin{array}{c}0.0019 \\
(0.0025)\end{array}$ & 0.0007 & $\begin{array}{c}-0.0039 \\
(0.0047)\end{array}$ & -0.0010 & $\begin{array}{l}0.0057 * * \\
(0.0028)\end{array}$ & 0.0027 \\
\hline Mandatory Dividend & $\begin{array}{l}0.0450^{* *} \\
(0.0198)\end{array}$ & 0.0164 & $\begin{array}{l}0.0399 * * \\
(0.0175)\end{array}$ & 0.0109 & $\begin{array}{c}0.0323 \\
(0.0374)\end{array}$ & 0.0146 \\
\hline Corruption & $\begin{array}{c}-0.0028 \\
(0.0111)\end{array}$ & -0.0010 & $\begin{array}{c}-0.0018 \\
(0.0133)\end{array}$ & -0.0005 & $\begin{array}{c}-0.0066 \\
(0.0178)\end{array}$ & -0.0030 \\
\hline Infrastructure & $\begin{array}{c}-0.0007 \\
(0.0121)\end{array}$ & -0.0003 & $\begin{array}{c}-0.0004 \\
(0.0144)\end{array}$ & -0.0001 & $\begin{array}{c}0.0000 \\
(0.0197)\end{array}$ & 0.0000 \\
\hline Capital Control & $\begin{array}{c}0.0017 \\
(0.0100)\end{array}$ & 0.0006 & $\begin{array}{c}0.0019 \\
(0.0156)\end{array}$ & 0.0005 & $\begin{array}{c}-0.0027 \\
(0.0121)\end{array}$ & -0.0012 \\
\hline Intercept & $\begin{array}{c}-0.0985^{* * *} \\
(0.0118)\end{array}$ & -0.0359 & $\begin{array}{c}-0.0800^{* * *} \\
(0.0165)\end{array}$ & -0.0219 & $\begin{array}{c}-0.1063 * * * \\
(0.0163)\end{array}$ & -0.0482 \\
\hline Scale & $\begin{array}{c}0.0259 \\
(0.0016)\end{array}$ & & $\begin{array}{c}0.0261 \\
(0.0024)\end{array}$ & & $\begin{array}{c}0.0251 \\
(0.0020)\end{array}$ & \\
\hline
\end{tabular}


TABLE 4 (continued)

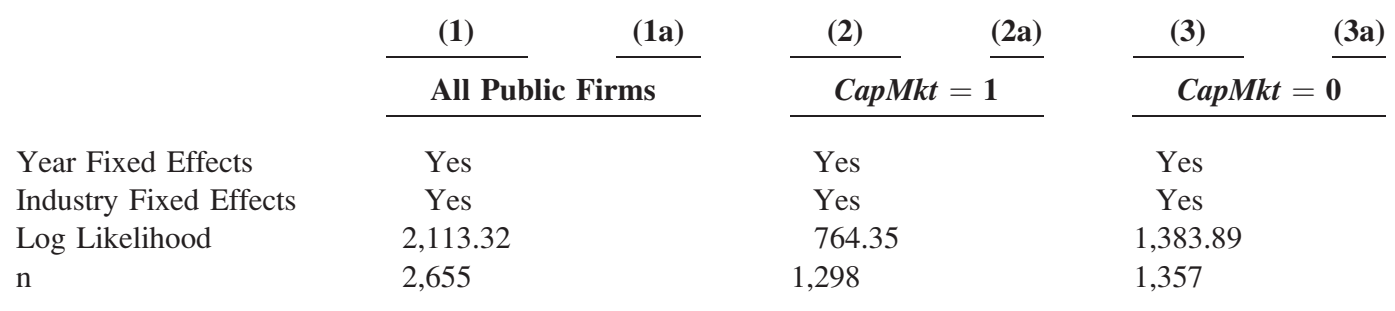

$*$,**,*** Significant at the 10 percent, 5 percent, and 1 percent two-tailed levels, respectively.

Robust standard errors are reported in parentheses.

Columns (1), (2), and (3) report coefficients from the Tobit estimation. Columns (1a), (2a), and (3a) report the marginal effect of each variable on the unconditional expected value of Repatriations. Details on these calculations are available from the authors. See Appendix A for variable definitions.

Ownership and Holding Company as control variables and run sensitivity tests using several other measures of tax-planning activity. ${ }^{26}$ To further rule out this possibility, we investigate whether the higher sensitivity of repatriation to the repatriation tax rate for high PRE firms (HighPre $=1)$ is concentrated in firms facing greater capital market pressure $(C a p M k t=1)$. We report these results in Table 4, Columns (2) and (3). Consistent with the earnings consequences of repatriation acting as a greater deterrent to repatriation in the presence of high capital market pressure, the interaction term, HighPre $\times$ RepTR, is negative and significant for firms with CapMkt $=1$ but is insignificant for firms with CapMkt $=0 .^{27,28}$

\section{Foreign Cash Holdings}

Next, we evaluate the association between the unrecognized expense for repatriation taxes and foreign cash holdings for the public firms in our sample. Although we conjecture that reporting incentives lead to predictable differences in repatriation across high and low PRE firms, our results could still be attributable to varying investment opportunities. A public firm that designates earnings as PRE is declaring its intention to reinvest foreign earnings abroad indefinitely and may, as a result of investment opportunities, be more sensitive to the repatriation tax rate. To control for this possibility, we include measures of foreign and domestic after-tax return on assets in our main empirical tests. As a sensitivity test, we replace measures of foreign and domestic return on assets with proxies for anticipated domestic and foreign growth

\footnotetext{
${ }^{26}$ Results are robust to using measures of tax aggressiveness from existing literature. Specifically, results are unchanged when we include a tax shelter score from Wilson (2009) or Lisowsky (2010). A tax shelter score is the predicted probability that a firm is engaging in a tax shelter, conditional on a set of firm characteristics. Those firm characteristics and the coefficients are documented by Wilson (2009) and Lisowsky (2010), who use samples of tax shelter participants to develop their models. Results are also unchanged when we include the percent of affiliates located in tax havens as a measure of tax aggressiveness, where tax havens are defined as in Hines and Rice (1994). In addition, the coefficients on each of these alternative measures are insignificant.

${ }^{27}$ Results are similar if we evaluate each condition used to define CapMkt separately. However, in these tests we use medians rather than quartiles to define each condition to create relatively equal sample sizes. When we define partitions based on the median of ERC, the coefficient on HighPre $\times$ RepTR is $-0.0426(\mathrm{t}=-1.92)$ for observations above the median and $-0.0382(\mathrm{t}=-1.28)$ for observations below the median. The coefficient on HighPre $\times$ RepTR is $-0.0515(\mathrm{t}=-2.48)$ for observations with BEAT above the median and $-0.0005(\mathrm{t}=-0.02)$ for observations with BEAT below the median. The coefficient on HighPre $\times$ RepTR is $-0.0697(\mathrm{t}=-2.13)$ for observations with $D E D$ below the median and $-0.0305(\mathrm{t}=-1.27)$ for observations with $D E D$ above the median.

${ }^{28}$ We avoid using a three-way interaction term because of the problems of interpreting such an effect in a Tobit model (Ai and Norton 2003).
} 
opportunities. To further rule out the possibility that our results are confounded by differences in investment opportunities, we follow Foley et al. (2007) and investigate the effect of tax expense deferral on foreign cash holdings.

Foley et al. (2007) find that repatriation taxes help explain the build-up of cash abroad and, more specifically, in affiliates located in low-tax jurisdictions. If an MNC designates foreign earnings as PRE because they are invested in profitable activities, then HighPre will have either a negative or insignificant effect on the association between the repatriation tax rate and foreign cash holdings because these profitable investments are not reflected in the cash account. However, to the extent that public companies designate foreign earnings as PRE because of the earnings effect of repatriations, we expect that these consequences will result in more cash held abroad, i.e., they will exacerbate the positive relation between the repatriation tax rate and foreign cash holdings.

To investigate this conjecture we estimate the following empirical model, which closely follows Foley et al. (2007), using ordinary least squares (OLS): ${ }^{29}$

$$
\begin{aligned}
L N(\text { Cash } / \text { Net Assets })= & \beta_{0}+\beta_{1} \text { RepTR }+\beta_{2} \text { HighPre }+\beta_{3} \text { HighPre } \times \text { RepTR } \\
& +\sum \beta_{k} \text { Controls }_{k}+\sum \beta_{t} \text { Year }_{t}+\sum \beta_{j} \text { Industry }_{j}+\varepsilon .
\end{aligned}
$$

$L N($ Cash/Net Assets $)$ is the natural log of foreign cash holdings divided by non-cash worldwide assets consistent with Foley et al. (2007). Foreign Investment is foreign R\&D plus foreign capital expenditures divided by worldwide assets. All other variables are defined as in Equation (1). We include Foreign ROA to control for investment opportunities abroad. As investment opportunities increase, we expect firms to hold less cash because the cash will be invested in productive assets. However, the precautionary motive to hold cash suggests that firms with better investment opportunities will hold more cash to ensure that they do not miss out on profitable investment opportunities due to adverse shocks (Opler et al. 1999). We include U.S. ROA to control for investment opportunities in the United States. We expect a negative coefficient if firms are more likely to repatriate when U.S. profitability increases and a positive coefficient if firms are less likely to repatriate when domestic operations are generating more cash. Size controls for the transaction motive to hold cash, which predicts that, since there are economies of scale when converting noncash assets into cash, large firms hold less cash (Baumol 1952; Miller and Orr 1966). Foreign Leverage controls for the need to use cash to meet debt obligations and we expect a negative coefficient. Foreign Investment controls for the use of cash to invest in capital assets and research and development. We expect a negative coefficient to the extent that these investments consume cash and a positive coefficient to the extent that this variable proxies for growth opportunities (Bates et al. 2009). All other variables control for the effect of repatriations on cash, thus predictions are opposite those in Equation (1).

We report the results of estimating Equation (2) for our sample of public firms in Table 5. We expect and find that the coefficient on HighPre $\times$ RepTR is positive and significant. ${ }^{30}$ This result is consistent with the view that undistributed foreign earnings are trapped abroad for firms with stronger reporting incentives and helps rule out the possibility that the results in Table 4 stem from higher investment opportunities abroad for high PRE firms. The insignificant coefficient on Foreign $R O A$ suggests that the investment effect and precautionary motive offset one another. The positive

\footnotetext{
${ }^{29}$ We use OLS to be consistent with Foley et al. (2007) and because it is not feasible that cash balances are negative, making Tobit inappropriate.

${ }^{30}$ This result is robust when we replace Foreign ROA and U.S. ROA with measures of foreign growth opportunities (three-year historical foreign sales growth by country and industry and weighted by affiliate assets in the affiliates country and industry) and domestic growth opportunities (three-year historical domestic sales growth by industry), respectively.
} 


\section{TABLE 5}

\section{Reporting Incentives and Foreign Cash Holdings Dependent Variable $=L N($ Cash $/$ Net Assets $)$}

Foreign Leverage

Foreign Investment

U.S. Loss

Mandatory Dividend

Corruption

Infrastructure

Capital Control

Intercept

Year Fixed Effects Industry Fixed Effects Adj. $\mathrm{R}^{2}$

$\mathrm{n}$
(1)

\begin{tabular}{c}
\hline-0.0655 \\
$(0.0695)$ \\
0.2143 \\
$(0.1447)$ \\
$2.0581^{*}$ \\
$(1.2558)$ \\
0.9738 \\
$(0.7001)$ \\
0.2296 \\
$(0.2296)$ \\
$-0.0720^{* *}$ \\
$(0.0374)$
\end{tabular}

$$
\text { (0.0374) }
$$

(2)

$-0.5739$

(0.7519)

$0.1849^{*}$

(0.1323)

2.5717 **

(1.1810)

0.8158

(0.6099)

1.1130 **

(0.4779)

$-0.0438$

(0.0351)

0.0676

(0.3596)

$12.6904 * * *$

(1.9205)

$0.3523 * * *$

(0.1094)

$-0.8850$

(1.6526)

1.0484

(0.7305)

$-1.6615^{* *}$

(0.8244)

0.2548

(0.4634)

$-3.8206^{* * * *}$

(0.6458)

$-4.2266^{* * *}$

(0.6592)

Yes

Yes

$18.56 \%$

2,655

$*$,**, *** Significant at the 10 percent, 5 percent, and 1 percent two-tailed levels, respectively.

Robust standard errors from OLS regressions are reported in parentheses.

$L N($ Cash/Net Assets $)$ is the natural log of foreign cash divided by non-cash worldwide assets. Foreign Investment is foreign capital expenditures plus foreign R\&D divided by worldwide assets. See Appendix A for definitions of all other variables.

coefficient on U.S. ROA in Column (2) suggests that domestically profitable firms' lower need for cash in the U.S. outweighs the investment effect, but only after including the full set of control variables. The negative coefficient on Size in Column (1) is consistent with the transaction motive to hold cash. However, this effect becomes insignificant in Column (2). The positive coefficient on Foreign Investment suggests that this variable is a proxy for growth opportunities and is consistent with existing research that finds that firms with better investment opportunities hold more cash (Opler et al. 1999). 


\section{CONCLUSION}

U.S. international tax policy plays a role in the ability of U.S. multinationals (MNCs) to compete in the global marketplace and various opponents of current tax policy argue that it creates incentives for U.S. firms to park foreign affiliate profits in low-tax countries, thereby reducing domestic investment. These incentives arise because MNCs incur a tax cost upon repatriation of foreign affiliate earnings generally equal to the difference between the U.S. tax rate and the average foreign tax rate paid on the repatriated earnings. A factor that has received little attention in the empirical literature on repatriation behavior is that the accounting for repatriation taxes can also affect repatriation decisions.

Financial reporting rules allow firms to delay recognition of a repatriation tax expense in the period in which the firm generates the earnings by designating them as permanently reinvested earnings (PRE) under the Indefinite Reversal Exception. Instead, the firm recognizes any unrecognized repatriation tax expense in the period that it repatriates those earnings. Firms that face reporting incentives to consistently report strong earnings numbers have an incentive to delay repatriation to avoid recognizing a repatriation tax expense in the financial statements.

We find that reporting incentives deter repatriations. Specifically, we find that repatriation by public firms is more sensitive to the repatriation tax rate than repatriation by private firms. In a sample of only public firms, we find that repatriation by firms with a high price-sensitivity to earnings and/or by firms that make extensive use of the PRE designation such that they would recognize a larger repatriation tax expense upon repatriation are more sensitive to the repatriation tax rate than repatriation by other firms. Our findings are relevant for both tax policy makers and accounting standard-setters because they suggest that the current financial reporting rules for the U.S. tax on foreign affiliate earnings deter repatriation and contribute to the nearly \$1 trillion MNCs have parked outside the United States. In light of recent debates regarding the merits of the U.S. system of worldwide taxation with deferral and its contribution to the pool of funds overseas, our results suggest that merely eliminating deferral of income tax expense recognition could significantly reduce incentives to park profits outside the U.S. without eliminating deferral of income tax payments. However, as net income is often relied upon by market participants to evaluate firm performance, the elimination of the Indefinite Reversal Exception could adversely affect U.S. firms' international capital market competiveness.

\section{REFERENCES}

Abarbanell, J., and R. Lehavy. 2003. Can stock recommendations predict earnings management and analysts' earnings forecast errors? Journal of Accounting Research 41 (1): 1-31.

Ai, C., and E. Norton. 2003. Interaction terms in logit and probit models. Economics Letters 80: 123-129.

Altshuler, R., and H. Grubert. 2003. Repatriation taxes, repatriation strategies and multinational financial policy. Journal of Public Economics 87: 73-107.

Altshuler, R., and T. S. Newlon. 1993. The effects of United States tax policy on the income repatriation patterns of U.S. multinational corporations. In Studies in International Taxation, edited by A. Giovannini, G. Hubbard, and J. Slemrod, 77-115. Chicago, IL: University of Chicago Press.

Altshuler, R., T. S. Newlon, and W. C. Randolph. 1995. Do repatriation taxes matter? Evidence from the tax returns of U.S. multinationals. In The Effects of Taxation on Multinational Corporations, edited by M. Feldstein, J. R. Hines Jr., and R. G. Hubbard, 252-272. Chicago, IL: University of Chicago Press.

Badertscher, B., S. Katz, and S. Rego. 2011. The Impact of Private Equity Ownership on Corporate Tax Avoidance. Working paper, University of Notre Dame, Columbia University, and Indiana University.

Barth, M., J. Elliott, and M. Finn. 1999. Market rewards associated with patterns of increasing earnings. Journal of Accounting Research 37: 387-413. 
Bates, T., K. Kahle, and R. Stulz. 2009. Why do U.S. firms hold so much more cash than they used to? Journal of Finance 64 (5): 1985-2021.

Baumol, W. 1952. The transaction demand for cash: An inventory theoretic approach. Quarterly Journal of Economics 66: 545-556.

Bear Sterns and Company. 2005. The JOBS Act: Repatriation guidance issued. Equity Research Report (January 13).

Beatty, A., and D. Harris. 1999. The effects of taxes, agency costs, and information asymmetry on earnings management: A comparison of public and private firms. Review of Accounting Studies 4 (3/4): 299-326.

Brumbaugh, D. L. 2003. Tax exemption for repatriated foreign earnings: Proposals and analysis. CRS Report for Congress. Washington, D.C.: Congressional Research Service.

Bureau of National Affairs (BNA). 2010. U.S. Tax-Related Accounting Issues of Multinational Corporations. Tax Management Foreign Income Portfolio No. 948. Tax Management Inc., Bureau of National Affairs. Arlington, VA: BNA.

Bushee, B. 1998. The influence of institutional investors on myopic R\&D investment behavior. The Accounting Review 73 (3): 305-334.

Carter, M. E., L. Lynch, and I. Tuna. 2007. The role of accounting in the design of CEO equity compensation. The Accounting Review 82: 327-357.

Chaney, P. L., and D. C. Jeter. 1992. The effect of size on the magnitude of long-window earnings response coefficients. Contemporary Accounting Research 8: 540-560.

Cloyd, C. B., J. Pratt, and T. Stock. 1996. The use of financial accounting choice to support aggressive tax positions: Public and private firms. Journal of Accounting Research 34: 23-43.

Collins, D., and S. Kothari. 1989. An analysis of inter-temporal and cross-sectional determinants of earnings response coefficients. Journal of Accounting and Economics 11 (2/3): 143-181.

Dechow, P., W. Ge, and C. Schrand. 2010. Understanding earnings quality: A review of the proxies, their determinants and their consequences. Journal of Accounting and Economics 50: 344-401.

Degeorge, F., J. Patel, and R. Zeckhauser. 1999. Earnings management to exceed thresholds. Journal of Business 72: 1-33.

Desai, M., C. F. Foley, and J. R. Hines. 2001. Repatriation taxes and dividend distortions. National Tax Journal 54:829-851.

Desai, M., C. F. Foley, and J. R. Hines. 2003. Chains of ownership, regional tax competition, and foreign direct investment. In Foreign Direct Investment in the Real and Financial Sector of Industrial Countries, edited by H. Herrmann, and R. Lipsey, 61-98. Heidelberg, Germany: Springer Verlag.

Desai, M., C. F. Foley, and J. R. Hines. 2007. Dividend policy inside the multinational firm. Financial Management 36: 5-26.

Faulkender, M., and M. Petersen. 2006. Does the source of capital affect capital structure? Review of Financial Studies 19 (1): 45-79.

Financial Accounting Standards Board (FASB). 2009. Income Taxes. Accounting Standards Codification (ASC) Topic 740. (July 1). Norwalk, CT: FASB. Available at: http://asc.fasb.org

Foley, C. F., J. Hartzell, S. Titman, and G. Twite. 2007. Why do firms hold so much cash? A tax-based explanation. Journal of Financial Economics 86: 579-607.

Graham, J., M. Hanlon, and T. Shevlin. 2011. Real effects of accounting rules: Evidence from multinational firms' investment location and profit repatriation decisions. Journal of Accounting Research 49 (1): 137-185.

Greene, W. 2003. Econometric Analysis. Englewood Cliffs, NJ: Prentice Hall.

Grubert, H. 1998. Taxes and the division of foreign operating income among royalties, interest, dividends and retained earnings. Journal of Public Economics 68: 269-290.

Hanlon, M., L. Mills, and J. Slemrod. 2007. An empirical examination of corporate tax noncompliance. In Taxing Corporate Income in the 21 st Century, edited by A. Auerbach, J. R. Hines Jr., and J. Slemrod, 171-210. Cambridge, MA: Cambridge University Press.

Hartman, D. G. 1985. Tax policy and foreign direct investment. Journal of Public Economics 26: 107-21.

Hines, J. R., and R. G. Hubbard. 1990. Coming home to America: Dividend repatriations by U.S. multinationals. In Taxation in the Global Economy, edited by A. Razin, and J. Slemrod, 161-200. Chicago, IL: University of Chicago Press. 
Hines, J., and E. Rice. 1994. Fiscal paradise: Foreign tax havens and American business. Quarterly Journal of Economics 109: 149-182.

International Monetary Fund (IMF). 2006. Annual report on exchange agreements and exchange restrictions. Library of Congress. Washington, D.C.: Government Printing Office.

Kormendi, R., and R. Lipe. 1987. Earnings innovation, earnings persistence, and stock returns. Journal of Business 60: 323-345.

Kothari, S. P. 2001. Capital markets research in accounting. Journal of Accounting and Economics 31: 105231.

Krull, L. 2004. Permanently reinvested earnings, taxes, and earnings management. The Accounting Review 79: 745-767.

La Porta, R., F. Lopez-De-Silanes, A. Shleifer, and R. Vishny. 1998. Law and finance. Journal of Political Economy 106: 1113-1156.

La Porta, R., F. Lopez-De-Silanes, A. Shleifer, and R. Vishny. 1999. The quality of government. Journal of Law, Economics, and Organization 15: 222-279.

Lisowsky, P. 2010. Seeking shelter: Empirically modeling tax shelters using financial statement information. The Accounting Review 85: 1693-1720.

Mataloni, R. 2003. U.S. multinational companies: Operations in 2001. Survey of Current Business: 85-105.

McDonald, J., and R. Moffitt. 1980. The uses of tobit analysis. The Review of Economics and Statistics: 318-321.

Mikhail, M. 1999. Coordination of earnings, regulatory capital and taxes in private and public companies. Unpublished paper, Arizona State University.

Miller, M., and D. Orr. 1966. A model of the demand for money by firms. Quarterly Journal of Economics 80: 413-435.

Opler, T., L. Pinkowitz, R. Stulz, and R. Williamson. 1999. The determinants and implications of corporate cash holdings. Journal of Financial Economics 52: 3-46.

Penno, M., and D. T. Simon. 1986. Accounting choices: Public versus private firms. Journal of Business, Finance, and Accounting 13: 561-568.

Power, L., and G. Silverstein. 2007. The foreign source income repatriation patterns of U.S. parents in worldwide loss. National Tax Journal 60: 537-549.

Redmiles, M. 2008. The one-time received dividend deduction. IRS Statistics of Income Bulletin (Spring).

Shackelford, D., J. Slemrod, and J. Sallee. 2011. Financial reporting, taxes and real decisions: A unifying framework. International Tax and Public Finance 18: 461-494.

Tobin, J. 1958. Estimation of relationships for limited dependent variables. Econometrica 26: 24-36.

Wilson, R. 2009. An examination of corporate tax shelter participants. The Accounting Review 84: 969-999.

Wolfson, M. 1993. The effects of ownership and control on tax and financial reporting policy. Economic Notes 22: 318-332.

Wooldridge, J. 2002. Econometric Analysis of Cross Section and Panel Data. Cambridge, MA: MIT Press.

Zion, D., A. Varshney, and C. Cornett. 2010. Taxes going up. Credit Suisse Equity Research Accounting and Tax Report (February 5).

\section{APPENDIX A \\ REGRESSION VARIABLES \\ Variable Name, Definition, and Source (BEA unless otherwise noted)}

\section{Dependent Variables}

Repatriations $=$ current-year repatriations scaled by worldwide assets.

\section{Variables of Interest}

Reporting Incentives:

H1A: Public $=1$ if the firm has publicly traded equity, 0 otherwise; 
H1B: $C a p M k t=1$ if the firm's $E R C$ is in the top quartile of the sample, BEAT is in the top quartile, or $D E D$ is in the bottom quartile, 0 otherwise; and

$\mathrm{H} 2$ : HighPre $=1$ if the firm's ratio of permanently reinvested earnings divided by total assets in low-tax affiliates $\geq 1$ in a benchmark year (1999 or 2004), 0 otherwise. Lowtax affiliates are those with Affiliate Creditable Tax Rate $\leq 30$ percent.

$E R C=$ firm's long-window ERC estimated by regressing 16-month cumulative abnormal returns on the change in annual earnings, excluding extraordinary items and discontinued operations, scaled by the market value of equity at the beginning of the year;

$B E A T=$ proportion of quarters that the firm appears in $\mathrm{I} / \mathrm{B} / \mathrm{E} / \mathrm{S}$ for which it beat the median analyst EPS forecast by 1 cent or less. We estimate BEAT beginning in the first year the firm appears in $\mathrm{I} / \mathrm{B} / \mathrm{E} / \mathrm{S}$ or 1984 , whichever is later, and ending in the current year;

$D E D=$ proportion of the firm's stock owned by long-term institutional investors (i.e., dedicated investors) as defined by Bushee (1998);

RepTR $=$ our estimate of the rate of tax the firm would owe to the U.S. if it repatriated all undistributed foreign earnings, computed as the U.S. statutory rate (35 percent) minus Creditable Tax Rate;

Affiliate Creditable Tax Rate = for each year, we subtract dividends paid (repatriations) from pre-tax income to obtain an estimate of each affiliate's undistributed pre-tax income at the end of each year. We aggregate each affiliate's tax expense and undistributed pre-tax income over time beginning with the date the affiliate is first included in the BEA survey or 1982 (the first BEA survey), whichever comes last, and ending at the end of year $t-1$. This process results in an estimate of each affiliate's cumulative taxes paid on undistributed pre-tax income (CTP) and cumulative undistributed pre-tax income (CUPTI). Affiliate Creditable Tax Rate for year $t$ equals year $t-1$ CTP divided by year $t-1$ CUPTI; and

Creditable Tax Rate $=$ estimate of the ratio of an MNC's foreign tax credit to its pre-tax dividend if all undistributed earnings were repatriated. An MNC's year $t$ Creditable Tax Rate equals the ratio of year $t-1$ CTP summed across all of its affiliates to year $t-1$ CUPTI summed across all of its affiliates.

\section{Control Variables}

Foreign $R O A=$ foreign net income scaled by foreign assets;

U.S. $R O A=$ domestic net income scaled by domestic assets;

Size $=$ natural log of foreign sales;

Lag Repatriations = prior-year repatriations scaled by prior-year worldwide assets;

Indirect Ownership = ratio of indirectly owned affiliates to total affiliates;

Holding Company = ratio of holding company affiliates (NAICS code 5512) to total affiliates;

U.S. Leverage $=$ ratio of domestic short-term and long-term debt to domestic assets;

Foreign Leverage $=$ ratio of foreign short-term and long-term debt to foreign assets;

U.S. Interest Rate = ratio of domestic interest paid on domestic short-term and long-term debt;

Foreign Interest Rate $=$ ratio of foreign interest paid divided by foreign short-term and longterm debt;

\%Foreign Assets = ratio of foreign assets to worldwide assets;

U.S. Loss $=1$ if the U.S. parent reports a domestic pre-tax loss in the current year, 0 otherwise; Mandatory Dividend = country-level indicator variable equal to 1 if the country requires that dividends are paid to shareholders, 0 otherwise, weighted by the number of affiliates in each type of country (La Porta et al. 1998), available at: http://www.economics. harvard.edu/faculty/shleifer/dataset; 
Corruption $=$ country-level variable ranging from 1 to 10 indicating high and low corruption, respectively, weighted by the number of affiliates in each type of country (La Porta et al. 1999), available at: http://www.economics.harvard.edu/faculty/shleifer/dataset;

Infrastructure $=$ country-level variable ranging from 1 to 10 indicating low and high quality infrastructure, respectively, weighted by the number of affiliates in each type of country (La Porta et al. 1999), available at: http://www.economics.harvard.edu/faculty/shleifer/ dataset; and

Capital Control $=$ country-level indicator variable equal to 1 if the country restricts firms' ability to take funds out of the country, 0 otherwise, weighted by the number of affiliates in each type of country (IMF 2006). 
Reproduced with permission of the copyright owner. Further reproduction prohibited without permission. 